\title{
GARIS PANTAI SITUS BATU JAYA PADA ABAD KE-5 MASEHI, JAWA BARAT
}

(The Fifth Century Coastline of Batujaya, West Java)

\author{
Fadlan Syuaib Intan \\ Pusat Penelitian Arkeologi Nasional \\ Jl. Raya Condet, Pejaten No.4 Jakarta Selatan 1250 \\ Pos-el: geobugis@yahoo.co.id
}

\begin{tabular}{l}
\hline \multicolumn{1}{c}{ INFO ARTIKEL } \\
\hline Histori Artikel \\
Diterima : 1 Mei 2020 \\
Direvisi : 5 Juni 2020 \\
Disetujui : 12 Juni 2020 \\
\hline
\end{tabular}

Keywords:

Old coastline, site morphology, marine geology

\section{Kata kunci:}

Garis pantai tua, morfologi kawasan situs, geologi laut

\begin{abstract}
Batujaya contains cultural heritage from the Hindu-Buddhist period, an area that has not been intensively studied by environmentalists. This is the main issue in this study, which includes its general geological conditions. Therefore, the purpose of this study is to determine the geological conditions of Batujaya, including its marine geology, to find out the old coastline when the Batujaya existed then. The aim is to conduct a general surface geological mapping as an effort to present geological information. The research method begins with literature review, geological observations, land and sea sediment sampling, then proceed with mineralogical analysis in a laboratory, and data interpretation. Results of environmental observations provide information on the landscape of the Batujaya site and its surroundings consisting of the morphological unit of plains, and old stadium rivers, with rock formation of alluvial. The north coast of Karawang is about $6 \mathrm{~km}$ away from the Batujaya site, where the north coast of Karawang is grouped as a prograded coast. In terms of relative age, this beach originates from a submergent coast influenced by alluvial processes and wave oscillations and low-sloped beaches which angled $2^{\circ}-4^{\circ}$. The archaeological research of Batujaya, especially the 5th century coastline, is expected to contribute toward the reconstruction of the old environment of Batujaya.
\end{abstract}

\begin{abstract}
ABSTRAK
Batujaya menyimpan tinggalan budaya dari masa Hindu-Buddha, suatu kawasan yang belum intensif diteliti oleh ahli lingkungan. Hal inilah yang menjadi pokok permasalahan pada penelitian ini, yang mencakup kondisi geologi secara umum. Oleh sebab itu, maksud dari penelitian ini adalah untuk mengetahui kondisi geologi, termasuk geologi laut yaitu untuk mengetahui keberadaan garis pantai tua pada waktu situs Batujaya masih berfungsi. Tujuannya adalah untuk melakukan pemetaan geologi permukaan secara umum sebagai salah satu upaya untuk menyajikan informasi geologi. Metode penelitian diawali dengan kajian pustaka, pengamatan geologi, pengambilan sampel sedimen darat dan laut, kemudian dilanjutkan dengan analisis mineralogi di laboratorium, serta interpretasi data. Hasil pengamatan lingkungan memberikan informasi tentang bentang alam situs Batujaya dan sekitarnya terdiri dari satuan morfologi dataran, dan sungainya berstadia sungai tua, dengan batuan penyusun situs adalah aluvial. Pantai utara Karawang berjarak $\pm 6 \mathrm{~km}$ dari situs Batujaya, dimana oantai utara Karawang dikelompokkan sebagai pantai maju (prograded coast). Dari segi umur relatif, pantai ini berasal dari submergent coast, yang dipengaruhi oleh proses aluvial dan aksi gelombang serta pantai bersudut lereng rendah/landai dengan sudut lereng $2^{\circ}-4^{\circ}$. Penelitian arkeologi di situs Batujaya, khususnya garis pantai pada abad ke-5 diharapkan dapat memberikan sumbangan bagi rekonstruksi lingkungan masa lampau situs Batujaya.
\end{abstract}


PENDAHULUAN

Penelitian tentang perubahan garis pantai Karawang, di pusatkan di Kompleks Situs Batujaya yang termasuk wilayah Kabupaten Karawang, Provinsi Jawa Barat (Gambar 1). Situs ini terletak $\pm 45 \mathrm{~km}$ di sebelah timur Jakarta, dan \pm 6 $\mathrm{km}$ dari pantai utara Jawa Barat. Karawang adalah salah satu kabupaten di wilayah Provinsi Jawa Barat, yang secara geografis terletak pada koordinat antara 5'56'-6 $34^{\prime}$ Lintang Selatan dan $107^{\circ} 02^{\prime}-107^{\circ} 40^{\prime} \quad$ Bujur Timur. Kabupaten Karawang berbatasan di sebelah timur dengan Kabupaten Subang, sebelah barat dengan Kabupaten Bekasi, sebelah utara dengan Laut Jawa, sebelah selatan dengan Kabupaten Bogor dan Kabupaten Cianjur, sebelah tenggara dengan dengan Kabupaten Purwakarta (Badan Pusat Statistik, 2019).

Luas Kabupaten Karawang adalah $1.753,27 \mathrm{~km}^{2}$ atau 3,73\% dari luas Provinsi Jawa Barat. Karawang merupakan salah satu daerah yang memiliki lahan subur di Jawa Barat, sehingga sebagian besar lahannya digunakan untuk pertanian. Rata-rata curah hujan pada tahun 2018 berkisar antara $1-304 \mathrm{~mm}$ dan rata-rata hari hujan pada tahun 2018 adalah 6 hari per bulan. Curah hujan tertinggi terjadi pada bulan Februari, sementara curah hujan terendah terjadi pada bulan Agustus (Badan Pusat Statistik, 2019).

Pada tahun 1960-an, di kawasan pantai utara Jawa Barat (pantai Karawang?) ditemukan situs-situs Buni dan Bekasi yang dikenal dengan temuan fragmen tembikar yang memiliki kesamaan bentuk dan ragam hiasnya, dan kini dikenal dengan nama komplek tembikar Buni.

Besarnya potensi arkeologi di daerah ini kemungkinan juga karena letaknya yang cukup strategis bagi lintas perdagangan internasional pada awalawal abad Masehi perdagangan antara Cina dan kawasan Asia termasuk India sudah mulai ramai. Beberapa temuan fragmen dengan tipe rouletted ware, yang berasal dari Arikamedu di India dan diproduksi sekitar abad pertama Masehi, ditemukan juga di komplek percandian Batujaya. Temuan tersebut memberi indikasi bahwa pada awal abad Masehi, daerah di sekitar Pantai Karawang telah tumbuh permukiman-permukiman kuno dari periode prasejarah, dan telah melakukan kontak dengan dunia luar, sampai berlanjut pada periode sejarah (Indradjaya, 2012). 
Situs Batujaya pertama kali ditemukan pada tahun 1984 oleh Tim Jurusan Arkeologi Universitas Indonesia yang dipimpin oleh Ayatrohaedi, ketika tim tersebut mengadakan penelitian di Situs Cibuaya, Kecamatan Pedes, Kabupaten Karawang yang terletak sekitar $20 \mathrm{~km}$ di sebelah timur Batujaya (Djafar, 2010).

Sejak ditemukan pada tahun 1984 sampai saat ini, Kompleks situs Batujaya telah mengundang perhatian yang luas

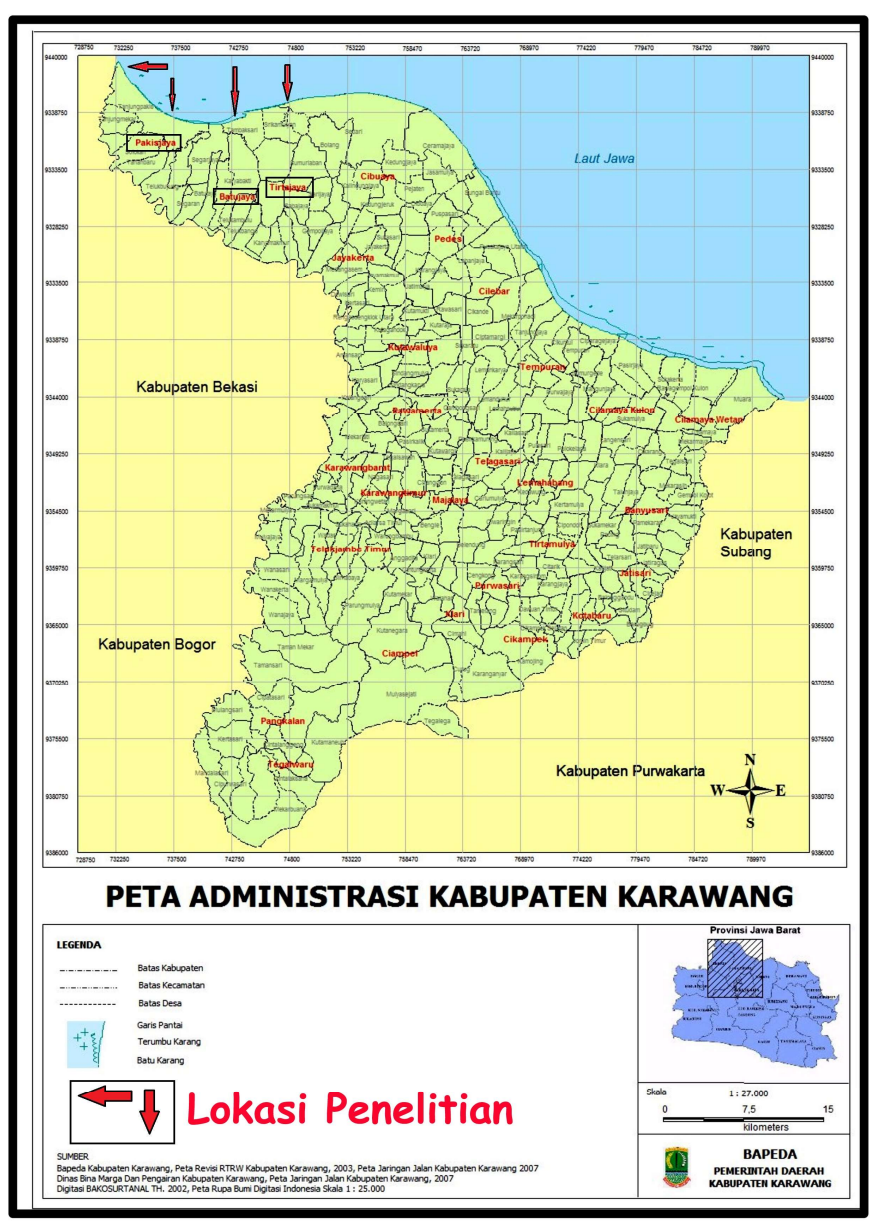

Gambar 1: Lokasi Penelitian dalam peta Kabupaten Karawang (Sumber: Bapeda Karawang, 2019) dari berbagai pihak untuk melakukan penelitian. Beberapa lembaga yang terlibat secara langsung dalam upaya mengungkap eksistensi situs ini adalah Pusat Penelitian Arkeologi Nasional, Universitas Indonesia (Jurusan Arkeologi) dan Balai Pelestarian Cagar Budaya (Indradjaya, 2012).

Klasifikasi jenis pantai yang digunakan di wilayah utara Karawang adalah berdasarkan Teori Cotton (1951:343-349; 1954:163-181) dan Shepard (1963). Kedua ahli tersebut sudah lama melakukan penelitianpenelitian jenis pantai menurut argumentasi mereka masing-masing. Secara fisik pantai utara Karawang dapat dikategorikan dalam jenis pantai maju (prograded coast). Tipe pantai ini berbentuk memanjang dengan sedikit gangguan morfologi berupa bukit. Jika ditinjau dari segi pembentukannya, Cotton (1954:163-181) berpendapat bahwa pantai ini terbentuk sebagai hasil dari erosi yang kemudian beralih atau digantikan oleh proses perkembangan pantai. Jenis pantai ini sangat umum terdapat dekat muara-muara sungai besar. Jika ditinjau dari segi umur relatif, maka pantai ini berasal dari submergent coast yang telah melewati masa dewasa 
(ratusan atau ribuan tahun), yang pada awalnya dimulai dengan proses erosi terhadap batuan sekitarnya, kemudian masa erosi ini digantikan oleh akumulasi sedimen pantai sampai saat sekarang. Tipe pantai seperti ini dicirikan oleh adanya tumpukan pasir gumuk di belakang garis pantai (backshore). Keadaan ini selalu terjadi ketika pembentukan pantai baru ke arah laut. Selanjutnya proses pembentukan pantai dipengaruhi oleh dua macam proses, yaitu proses aluvial (alluviation) dan aksi gelombang (wave action).

Pemerian pantai di atas sedikit berbeda dengan klasifikasi yang dikemukakan oleh Shepard (1963). Dia mengklasifikasikan pantai ini sebagai land deposition coast atau jenis pantai yang terbentuk karena hasil pengendapan dari daratan berkembang ke arah laut dan menamakannya pantai gumuk (dune coast). Meskipun istilah yang dipergunakan untuk pemerian jenis pantai tersebut berbeda (Cotton, 1951:343-349; Shepard, 1963) akan tetapi secara garis besarnya mempunyai makna sama dan kebenarannya bersifat relatif.

Menurut Shepard (1963) pantai dapat dibedakan berdasarkan variasi bentuk fisik profil pantai. Profil pantai sebenarnya adalah bentuk lereng pantai, bisa bersifat menerus atau mempunyai undak-undak. Dapat juga memperlihatkan lereng sangat landai tanpa tonjolan (berm) atau parit. Pengukuran kemiringan lereng pantai pada beberapa titik pengamatan di satuan morfologi dataran menghasilkan satu jenis kelerengan pantai, yaitu pantai bersudut lereng rendah atau landai (pantai yang termasuk pada satuan morfologi dataran) dengan sudut lereng $2^{\circ}-4^{\circ}$.

Permasalahan umum dalam penelitian ini, yaitu mengkaji kondisi geologi regional dan lokal yang erat kaitannya dengan bentuk lingkungan Situs Batujaya. Rumusan masalahnya adalah a) bagaimana kondisi bentang alam daerah telitian?; b) bagaimana stratigrafi daerah telitian?; dan c) bagaimana bentuk lingkungan pantai di utara Jawa Barat, khususnya di Karawang, serta sejauh mana perubahannya?. Maksud dari penelitian ini adalah untuk mengetahui kondisi geologi, termasuk geologi laut yaitu untuk mengetahui keberadaan garis pantai pada waktu Situs Batujaya masih berfungsi, sedangkan tujuannya adalah untuk melakukan pemetaan geologi 
permukaan secara umum sebagai salah satu upaya untuk menyajikan informasi geologi.

\section{METODE PENELITIAN}

Metode penelitian yang digunakan adalah kajian pustaka, dengan mempelajari lokasi penelitian dari peneliti terdahulu, melalui buku, jurnal, maupun dari internet; survei, dengan mengamati keadaan bentang alam, batuan penyusun situs, dan proses geologi laut yang pernah terjadi. Langkah analisis akan disesuaikan dengan kebutuhan dan urutan kerja geologi, yaitu:

* Geomorfologi, penentuan bentuk bentang alam akan mempergunakan Sistem Desaunettes (1977; dan Todd 1980), yang didasarkan atas besarnya kemiringan lereng dan beda tinggi relief suatu tempat. Hasil penentuan ini adalah pembagian wilayah berdasarkan ketinggian dalam bentuk persentase kelerengan. Pengamatan sungai dilakukan untuk melihat pola pengeringan (drainage basin), misalnya klasifikasi berdasarkan atas kuantitas air, pola dan stadia sungai;
* Litologi, menentukan nama batuan penyusun wilayah penelitian melalui analisis petrologi;

* Geologi laut, menentukan jenis pantai (apakah jenis pantai maju atau prograded coast, pantai gumuk atau dune coast), mengetahui proses pembentukan pantai beserta perubahannya melalui analisis mineralogi.

Data dari kajian pustaka dengan hasil lapangan dikompilasikan dengan hasil penelitian, dan langkah terakhir dilakukan interpretasi peta geologi dan peta topografi. Manfaat yang dapat diperoleh dalam penelitian ini, adalah menambah pengetahuan tentang kondisi geologi wilayah penelitian.

Secara geografis wilayah survei lingkungan Situs Batujaya tercantum pada Peta Rupa Bumi Indonesia lembar 1209-534 (Batujaya), lembar 1210-212 (Pakis), lembar 1210-211 (Biyongbong), 1210-122 (Muara Bendera) berskala 1:25.000. Batas wilayah penelitian untuk penentuan garis pantai, di sebelah utara adalah Laut Jawa, dan sebelah selatan adalah Sungai Citarum. Lokasi penelitian dapat dicapai dengan kendaraan beroda dua dan beroda empat, baik dari ibukota Kabupaten maupun dari Jakarta. 


\section{HASIL DAN PEMBAHASAN}

\section{Geologi Wilayah Situs Batujaya}

Kondisi geologi wilayah Situs Batujaya dan sekitarnya ditekankan kepada aspek bentang alam, stratigrafi, dan analisis mineralogi.

\section{a. Geomorfologi}

Morfologi atau bentuk bentang alam suatu daerah dipengaruhi oleh beberapa faktor yaitu, litologi, struktur geologi, stadia daerah, dan tingkat erosi (Thornbury, 1969). Bentuk lahan di Kabupaten Karawang sebagian besar adalah daratan yang relatif rata dengan variasi antara 0 - 5 meter di atas permukaan laut (dpl). Hanya sebagian kecil wilayah yang bergelombang dan berbukit-bukit dengan ketinggian antara 0 - 1.200 meter dpl.

Secara umum keadaan bentang alam (morfologi) wilayah Situs Batujaya memperlihatkan kondisi dataran rendah. Kondisi bentang alam seperti ini, apabila diklasifikasikan dengan mempergunakan Sistem Desaunettes (Desaunettes, 1977; dan Todd, 1980), yang berdasarkan atas besarnya persentase kemiringan lereng dan beda tinggi relief suatu tempat, maka Situs Batujaya dan sekitarnya termasuk dalam satuan morfologi dataran (Gambar 3), dengan ketinggian situs secara umum adalah 1 3 meter dpl. Satuan morfologi dataran, dengan persentase kemiringan lereng antara $0-2 \%$, dan menempati $100 \%$ dari wilayah pengamatan. Pembentuk satuan morfologi adalah endapan aluvial. Satuan morfologi dataran, pada umumnya diusahakan sebagai areal pemukiman lahan tambak dan lahan pertanian Gambar 4) (Intan, dkk., 1992; Intan, 2006; Intan, dkk., 2009). Kabupaten Karawang dilalui oleh aliran sungai yang melandai ke utara arah Sungai Citarum dan merupakan pemisah antara Kabupaten Karawang dengan Kabupaten Bekasi, sedangkan Sungai Cilamaya merupakan batas wilayah dengan Kabupaten Subang. Selain sungai, terdapat juga tiga saluran irigasi yang besar yaitu Saluran Induk Tarum Utara, Saluran Induk Tarum Tengah, dan Saluran Induk Tarum Barat yang dimanfaatkan untuk pengairan sawah, tambak dan keperluan industri (Badan Pusat Statistik, 2019). Sungai-sungai yang mengalir di wilayah Situs Batujaya dan sekitarnya, terbagi atas dua kelompok sungai, yaitu: sungai alam, dan sungai alam yang mengalami pelurusan oleh manusia. 
Yang termasuk dalam kelompok sungai alam, adalah Sungai Citarum. Sungai Citarum (Gambar 4) merupakan sungai induk yang mengalir di situs Batujaya dan sekitarnya. Sungai Citarum berhulu di lereng Gunung Wayang, Malabar. Sungai Citarum adalah sungai yang terbesar di Jawa Barat, berarah aliran tenggara - baratlaut, lebarnya antara 40-60 meter, terutama di daerah hilir. Sebelum mendekati muara di Laut

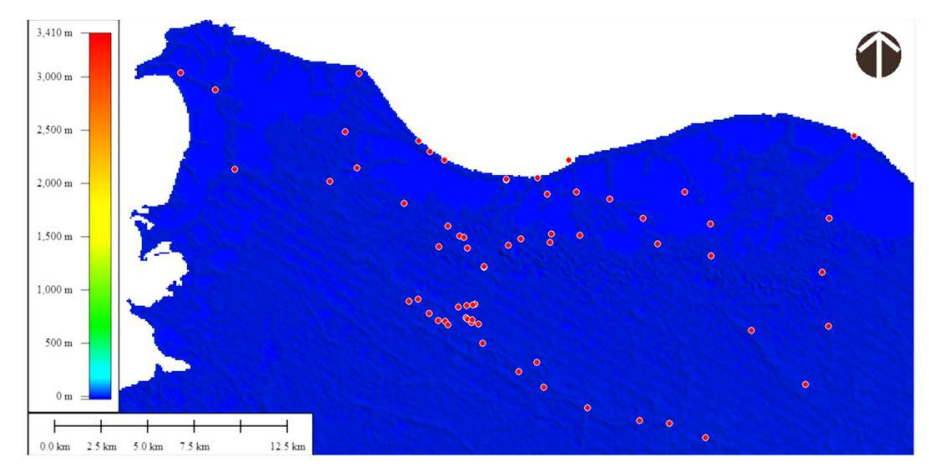

Gambar 2. Peta bentang alam, lokasi stasiun pengamatan, dan lokasi pengambilan sampel sedimen di wilayah penelitian (noktah merah) (Sumber: Intan 2020; Data Topografi berdasarkan Jarvis et al. 2008)

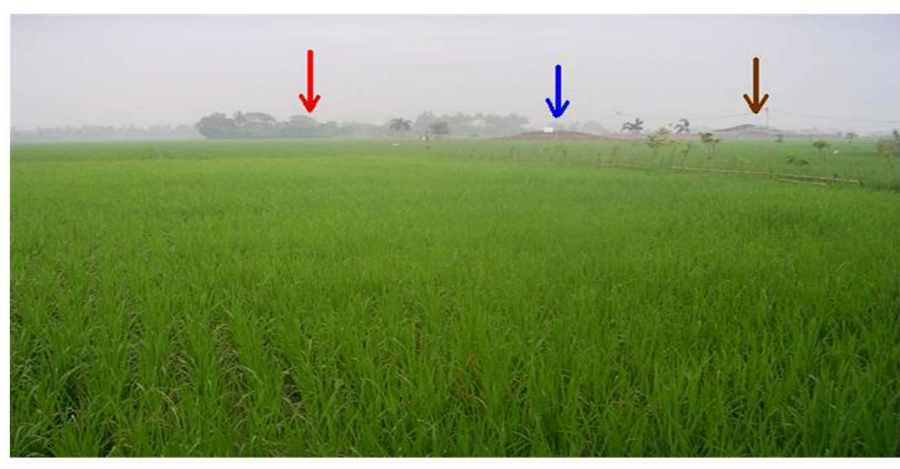

Gambar 3. Kenampakan satuan morfologi dataran yang dimanfaatkan sebagai lahan pertanian, tampak Unur Lempeng (panah merah), Candi Jiwa (panah biru) dan Candi Blandongan (panah coklat) (Sumber Dokumentasi Puslit Arkenas, 2009)
Jawa, Sungai Citarum terpecah menjadi tiga, yaitu Solo Bungin, Solo Balukbuk, dan Kali Muara Gembong. Ketiga cabang sungai ini membentuk delta kaki burung (birds foot delta) (Intan, dkk., 1992; Intan, 2006; Intan, dkk., 2009).

Sungai Citarum termasuk pada kelompok sungai yang berstadia tua (old river stadia) yang dicirikan dengan aliran sungai berkelok-kelok (meander), alirannya sangat tenang, sudah tidak dijumpai adanya air terjun ataupun danau di sepanjang aliran sungai, erosi horizontal lebih kuat dari erosi vertikal, lembahnya agak tumpul dan lebar serta berbentuk huruf "Ü", telah dijumpai adanya pulau-pulau tapal kuda (oxbow lake) (Lobeck, 1939; Thornbury, 1964).

Sungai alam yang mengalami pelurusan oleh manusia, adalah Kali Asin (mulai dari Kampung Kebon Kopi hingga ke saluran irigasi), Kali Kubang (mulai dari Kampung Teluk Buyung hingga ke saluran irigasi), Sungai Terong (mulai dari Kampung Sungai Terong 
Timur hingga ke saluran irigasi), Sungai

Tambak Sumur (mulai dari Kampung Cisoma hingga ke saluran irigasi)

(Gambar 5), Sungai Bantarkuning (mulai dari Kampung Karanganyar hingga ke saluran irigasi), dan beberapa sungai alam lainnya (Intan, 2006; Intan, dkk., 2009).

Kali Asin yang merupakan sebuah sungai alam berhulu di Dusun Kebun Kopi Desa Teluk Buyung, Kecamatan Pakis Jaya, secara umum

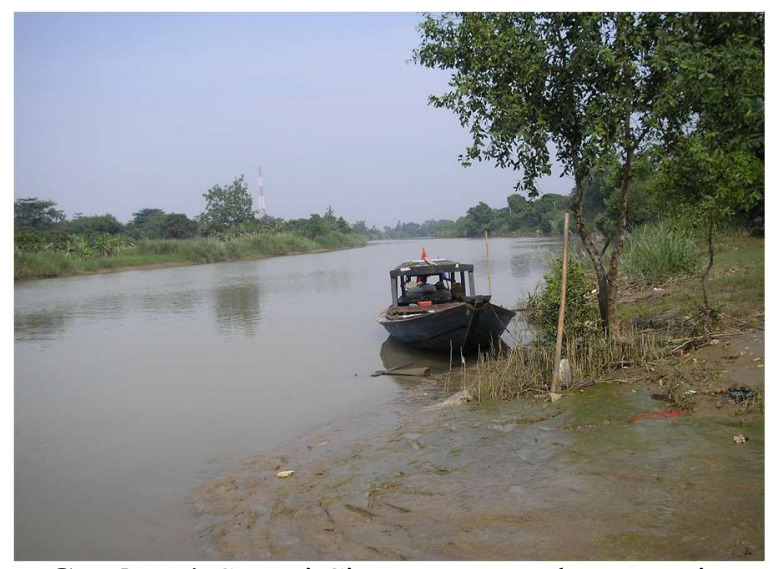

Gambar 4. Sungai Citarum, merupakan sungai induk-sungai alam yang bermuara di Laut Jawa (Sumber Dokumentasi Puslit Arkenas, 2009)

berarah aliran dari selatan ke utara dan bermuara di Kali Kubang. Kali Asin. Menurut Indradjaya (2005:45-59) bahwa Kali Asin merupakan jalur transportasi dari arah laut ke lokasi situs-situs di Batujaya (Indradjaya (2005:45-59).

Berdasarkan hasil pengamatan Intan (2006) dan Intan, dkk., (2009), Kali Asin yang berhulu di Dusun Kebun Kopi, merupakan sebuah sungai yang juga mendapat suplai air dari Kali Citarum. Pada saat Kali Citarum banjir, airnya meluap ke arah utara dan memasuki alur Kali Asin, sehingga air Kali Asin dapat mengalir ke arah utara. Namun pada saat Kali Citarum tidak menyuplai air ke Kali Asin, maka air yang terdapat di Kali Asin tidak mengalir atau cuma menjadi genangan air (Intan, 2006; Intan, dkk., 2009).

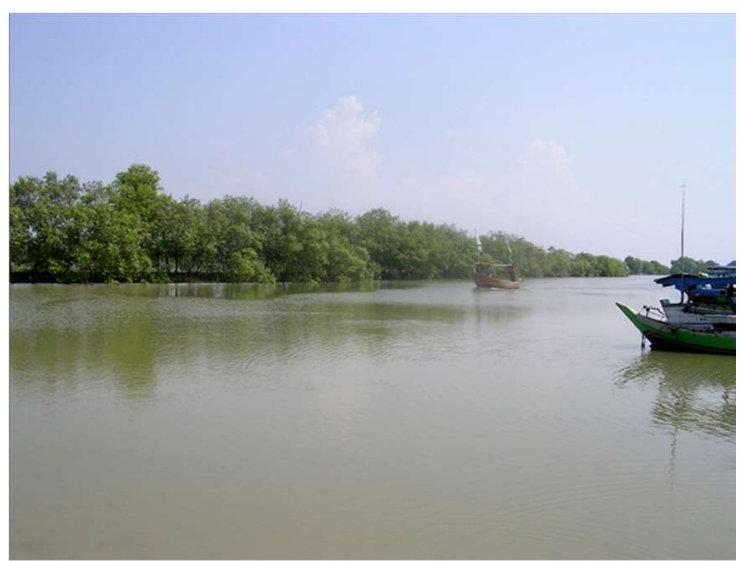

Gambar 5. kenampakan Sungai Tambak Sumur sebagai sungai alam yang telah mengalami pelurusan (Sumber Dokumentasi Puslit Arkenas, 2009)

\section{b. Stratigrafi}

Dataran Batujaya terbentuk dari endapan aluvial yang materi penyusunnya berasal dari pegunungan Bandung Selatan. Materialnya bersifat pasiran dan bertekstur halus. Dataran aluvial terbentuk dari endapan banjir Sungai Citarum di masa lalu (van 
Bemmelen, 1949). Daerah Batujaya merupakan dataran yang terbentuk oleh proses sedimentasi, yang disebabkan adanya erosi oleh kekuatan arus sungai. Proses erosi ini terjadi di masa lalu itu berlangsung terus-menerus sehingga laut, rawa, dan sungai purba di daerah ini terisi oleh bahan-bahan erosi.

Satuan batuan yang menyusun wilayah Situs Batujaya dan sekitarnya adalah endapan kuarter, hasil limpahan banjir dan endapan sedimen laut yang mempunyai sebaran datar dan tegak sebagai akibat perkembangan pantai. Ditemukannya endapan-endapan yang saling tumpang-tindih ini disebabkan oleh proses limpahan banjir dengan waktu yang relatif pendek (Intan, 2006; Intan, dkk., 2009).

Tatanan stratigrafi wilayah Situs Batujaya dan sekitarnya, menggunakan data hasil penelitian Prasetyo (1987) (dalam Intan dkk., 1992) sebagai berikut: 1. Satuan lempung, terdiri dari lempung, gambut, lanau, dan endapan rawa, dijumpai pada kedalaman sekitar 10-12 meter dari permukaan tanah, diendapkan dalam lingkungan rawa purba;

2. Satuan pasir, terdiri dari pasir kuarsa, fragmen batuan beku, cangkang kerang, dijumpai pada kedalaman 510 meter dari permukaan tanah, terbentuk akibat proses perkembangan pantai;

3. Satuan pasir lempungan, terdiri dari pasir lempungan, lanau, terbentuk pada lingkungan delta;

4. Satuan pasir, terdiri dari pasir, dengan struktur sedimen silang-siur, dan terdiri dari sedimen sungai purba, dan sedimen sungai resen;

5. Satuan lempung lanauan, berwarna kecoklatan hingga coklat kehitaman, plastis, ketebalan $40-60 \mathrm{~cm}$.

\section{c. Analisis Mineralogi}

Analisis yang dilakukan di laboratorium Pusat Penelitian Arkeologi Nasional adalah analisis mineralogi. Analisis mineralogi bertujuan untuk mengetahui jenis-jenis mineral lewat pengamatan sifat fisiknya, dengan menggunakan mikroskop. Dengan analisis mineralogi tersebut, akan dapat diketahui endapan-endapan darat dan endapan-endapan laut (pantai), yang pada akhirnya akan dapat dibuat garis pantai seperti dalam tujuan penelitian yang telah disebutkan di atas. Untuk melaksanakan analisis tersebut dibutuhkan beberapa sampel sedimen yang lokasi pegambilannya (Gambar 6) didasarkan 


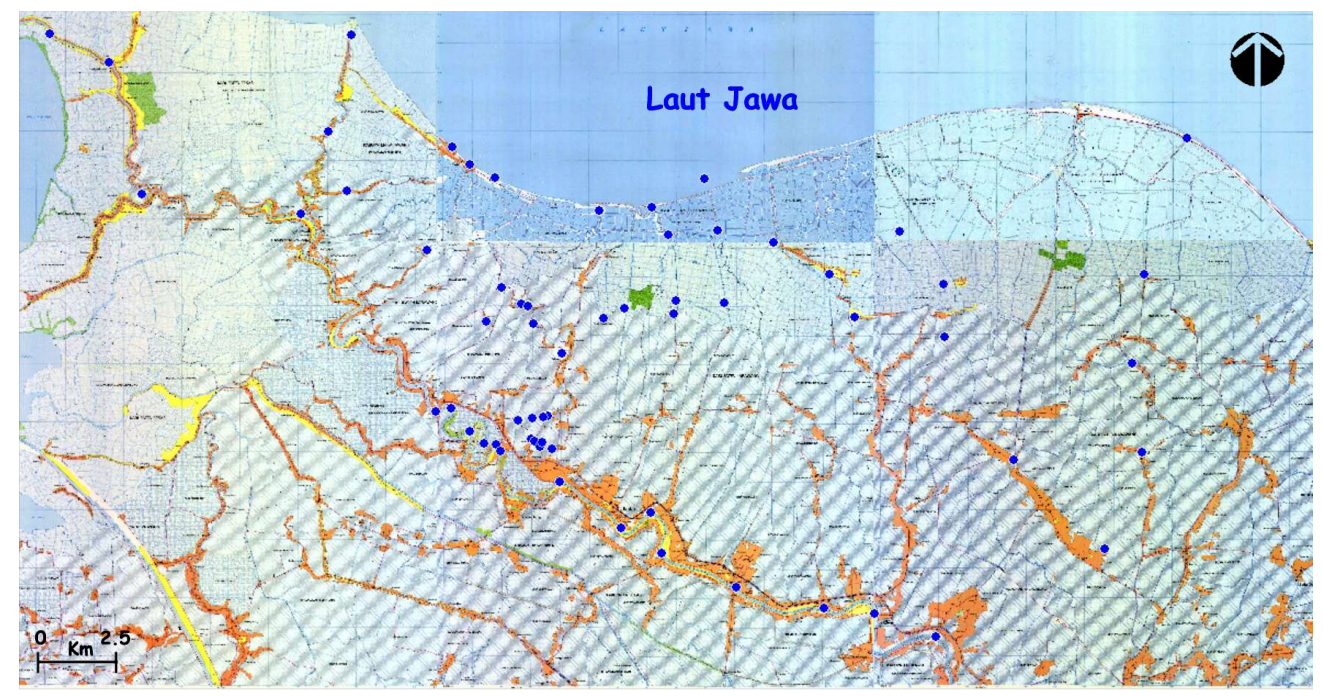

Gambar 6: Stasiun pengamatan dan lokasi pengambilan sampel sedimen di wilayah penelitian dalam Peta Rupa Bumi Indonesia (Sumber: Bakosurtanal, 1990, 1991, dan 2001, dengan pengolahan)

atas bentuk bentang alam wilayah Situs Batujaya dan sekitarnya. Pada penelitian ini telah diambil sampel-sampel sedimen pada beberapa lokasi (stasiun pengamatan) di sepanjang Sungai Citarum ke arah hilir (bagian utara), bagian tengah dataran Situs Batujaya, dan bagian utara yang berupa tepi pantai Laut Jawa. Lokasi pengambilan sampel sedimen yang seharusnya berada dalam wilayah Kabupaten Karawang, namun karena pengamatan lapangan yang diusahakan ke bagian hilir atau muara Sungai Citarum, terpaksa memasuki wilayah Kabupaten Bekasi. Sampelsampel sedimen tersebut, selanjutnya dianalisis di laboratorium Pusat
Penelitian Arkeologi Nasional, melalui analisis mineralogi. Analisis mineralogi untuk melihat sejauh mana persebaran aluvial (darat dan pantai) secara horizontal. Pengambilan sampel sedimen dilakukan di 61 stasiun pengamatan, namun yang di analisis di laboratorium sebanyak 52 sampel sedimen (tabel 1). Kemudian jenis sedimen dan warna sedimen yang diambil dapat dilihat pada tabel 2. Analisis mineralogi dilakukan oleh penulis di laboratorium Pusat Penelitian Arkeologi Nasional.

Penamaan mineral berdasarkan pada Kraus dkk. (1953); dan Ong dkk (1981) dan hasilnya dapat dilihat di tabel 3 
Tabel 1:

Lokasi Stasiun Pengamatan dan pengambilan Sampel Sedimen di Kabupaten Karawang dan Kabupaten Bekasi

\begin{tabular}{|c|c|c|c|c|c|c|c|}
\hline No. & Stasiun & Lokasi & Dusun & Desa & Kecamatan & Lintang Selatan & Bujur Timur \\
\hline 01 & 7 & $\begin{array}{l}\text { Muara Sungai } \\
\text { Sukajaya }\end{array}$ & Segarjaya & Segarjaya & Batujaya & $05^{\circ} 59^{\prime} 22,3^{\prime \prime}$ & $107^{\circ} 10^{\prime} 11,3^{\prime \prime}$ \\
\hline 02 & 8 & $\begin{array}{l}\text { Sungai Terong } \\
\text { Timur }\end{array}$ & $\begin{array}{l}\text { Sungai } \\
\text { Terong Timur }\end{array}$ & $\begin{array}{l}\text { Karya } \\
\text { Bakti }\end{array}$ & Batujaya & $06^{\circ} 00^{\prime} 57,5^{\prime \prime}$ & $107^{\circ} 12^{\prime} 19,5^{\prime \prime}$ \\
\hline 03 & 11 & $\begin{array}{l}\text { Muara Sungai } \\
\text { Cikiong }\end{array}$ & Cikiong & Segar Jaya & Batujaya & $05^{\circ} 59^{\prime} 19,1^{\prime \prime}$ & $107^{\circ} 11^{\prime} 04,9^{\prime \prime}$ \\
\hline 04 & 12 & Sungai Citarum & Sambo & $\begin{array}{l}\text { Kuta } \\
\text { Ampel }\end{array}$ & Batujaya & $06^{\circ} 06^{\prime} 17,2^{\prime \prime}$ & $107^{\circ} 14^{\prime} 54,3^{\prime \prime}$ \\
\hline 05 & 13 & Sungai Citarum & Teluk Ampel & $\begin{array}{l}\text { Karya } \\
\text { Makmur }\end{array}$ & Batujaya & $06^{\circ} 06^{\prime} 11,9^{\prime \prime}$ & $107^{\circ} 14^{\prime} 02,7^{\prime \prime}$ \\
\hline 06 & 14 & Sungai Citarum & Satu & $\begin{array}{l}\text { Teluk } \\
\text { Bango } \\
\end{array}$ & Batujaya & $06^{\circ} 05^{\prime} 50,1^{\prime \prime}$ & $107^{\circ} 12^{\prime} 31,8^{\prime \prime}$ \\
\hline 07 & 15 & Sungai Citarum & $\begin{array}{l}\text { Kelapa } \\
\text { Nunggal }\end{array}$ & Batujaya & Batujaya & $06^{\circ} 04^{\prime} 49,2^{\prime \prime}$ & $107^{\circ} 10^{\prime} 33,1 ”$ \\
\hline 08 & 21 & Sungai Terong & Medan Jaya & Baturaden & Batujaya & $06^{\circ} 01^{\prime} 08,8^{\prime \prime}$ & $107^{\circ} 11^{\prime} 27,7^{\prime \prime}$ \\
\hline 09 & 22 & Sungai Terong & $\begin{array}{l}\text { Sungai } \\
\text { Terong }\end{array}$ & $\begin{array}{l}\text { Karya } \\
\text { Bakti } \\
\end{array}$ & Batujaya & $06^{\circ} 00^{\prime} 54,9^{\prime \prime}$ & $107^{\circ} 11 ’ 29,6 ”$ \\
\hline 10 & 26 & Sungai Citarum & Goncai & $\begin{array}{l}\text { Teluk } \\
\text { Bango }\end{array}$ & Batujaya & $06^{\circ} 05^{\prime} 15,2^{\prime \prime}$ & $107^{\circ} 11^{\prime} 15,7^{\prime \prime}$ \\
\hline 11 & 27 & Sungai Citarum & Jatimulya & $\begin{array}{l}\text { Teluk } \\
\text { Ambulu }\end{array}$ & Batujaya & $06^{\circ} 04^{\prime} 33,7^{\prime \prime}$ & $107^{\circ} 11^{\prime} 04,0^{\prime \prime}$ \\
\hline 12 & 32 & $\begin{array}{l}\text { Kali Bambu } \\
\text { Kuning }\end{array}$ & Karang Anyar & Segar Jaya & Batujaya & $06^{\circ} 01^{\prime} 13,8^{\prime \prime}$ & $107^{\circ} 10^{\prime} 14,9^{\prime \prime}$ \\
\hline 13 & 33 & $\begin{array}{l}\text { Kali Bambu } \\
\text { Kuning }\end{array}$ & Karang Anyar & Segar Jaya & Batujaya & $06^{\circ} 01^{\prime} 03,3^{\prime \prime}$ & $107^{\circ} 10^{\prime} 37,0^{\prime \prime}$ \\
\hline 14 & 38 & $\begin{array}{l}\text { Situs Unur } \\
\text { Lempeng }\end{array}$ & Sumur & Segaran & Batujaya & $06^{\circ} 03^{\prime} 25,9^{\prime \prime}$ & $107^{\circ} 09^{\prime} 10,2^{\prime \prime}$ \\
\hline 15 & 39 & $\begin{array}{l}\text { Situs Candi } \\
\text { Blandongan }\end{array}$ & Sumur & Segaran & Batujaya & $06^{\circ} 03^{\prime} 21,2^{\prime \prime}$ & $107^{\circ} 09^{\prime} 12,0 "$ \\
\hline 16 & 40 & $\begin{array}{l}\text { Basecamp } \\
\text { Kaisin }\end{array}$ & Sumur & Segaran & Batujaya & $06^{\circ} 03^{\prime} 27,8^{\prime \prime}$ & $107^{\circ} 09^{\prime} 22,3^{\prime \prime}$ \\
\hline 17 & $47 \mathrm{~A}$ & Sungai Citarum & --- & Batujaya & Batujaya & $06^{\circ} 04^{\prime} 01,14^{\prime \prime}$ & $107^{\circ} 09^{\prime} 30,26^{\prime \prime}$ \\
\hline 18 & 50 & $\begin{array}{l}\text { Tambak } \\
\text { (temuan } \\
\text { tembikar) }\end{array}$ & $\begin{array}{l}\text { Karang } \\
\text { Mulya }\end{array}$ & Segar Jaya & Batujaya & $05^{\circ} 59^{\prime} 22,8^{\prime \prime}$ & $107^{\circ} 10^{\prime} 11,5^{\prime \prime}$ \\
\hline 19 & 61 & $\begin{array}{l}\text { Situs Batujaya/ } \\
\text { Sektor SPK - } \\
\text { Kotak TP1 }\end{array}$ & --- & --- & Batujaya & ---- & ---- \\
\hline 20 & 1 & Kali Asin & Kalijaya & Telaga Jaya & Pakis Jaya & $06^{\circ} 01^{\prime} 18,5^{\prime \prime}$ & $107^{\circ} 09^{\prime} 03,5^{\prime \prime}$ \\
\hline 21 & 2 & Kali Kubang & Wagirjaya & Telaga Jaya & Pakis Jaya & $06^{\circ} 00^{\prime} 58,7^{\prime \prime}$ & $107^{\circ} 08^{\prime} 50,3^{\prime \prime}$ \\
\hline 22 & 3 & $\begin{array}{l}\text { Pertemuan Kali } \\
\text { Kubang dengan } \\
\text { Kali Asin }\end{array}$ & Wagirjaya & Telaga Jaya & Pakis Jaya & $06^{\circ} 01^{\prime} 0,34^{\prime \prime}$ & $107^{\circ} 08^{\prime} 57,0^{\prime \prime}$ \\
\hline 23 & 4 & Kamal & Kamal & Tanah Baru & Pakis Jaya & $06^{\circ} 00^{\prime} 41,9^{\prime \prime}$ & $107^{\circ} 08^{\prime} 29,9^{\prime \prime}$ \\
\hline 24 & 5 & $\begin{array}{l}\text { Muara Sungai } \\
\text { Pakis }\end{array}$ & Pakis Satu & $\begin{array}{l}\text { Tanjung } \\
\text { Pakis }\end{array}$ & Pakis Jaya & $05^{\circ} 58^{\prime} 35,0^{\prime \prime}$ & $107^{\circ} 07^{\prime} 57,9^{\prime \prime}$ \\
\hline 25 & 6 & $\begin{array}{l}\text { Muara Sungai } \\
\text { Cipatar }\end{array}$ & Pakis Dua & $\begin{array}{l}\text { Tanjung } \\
\text { Pakis }\end{array}$ & Pakis Jaya & $05^{\circ} 58^{\prime} 49,2^{\prime \prime}$ & $107^{\circ} 08^{\prime} 23,9^{\prime \prime}$ \\
\hline 26 & 16 & Sungai Citarum & Tanjung Jaya & $\begin{array}{l}\text { Teluk } \\
\text { Buyung }\end{array}$ & Pakis Jaya & $06^{\circ} 03^{\prime} 23,7^{\prime \prime}$ & $107^{\circ} 08^{\prime} 24,7^{\prime \prime}$ \\
\hline
\end{tabular}




\begin{tabular}{|c|c|c|c|c|c|c|c|}
\hline No. & Stasiun & Lokasi & Dusun & Desa & Kecamatan & $\begin{array}{l}\text { Lintang } \\
\text { Selatan }\end{array}$ & $\begin{array}{l}\text { Bujur } \\
\text { Timur }\end{array}$ \\
\hline 27 & 17 & Kali Mati & Teno Jaya & $\begin{array}{c}\text { Teluk } \\
\text { Buyung }\end{array}$ & Pakis Jaya & $06^{\circ} 03^{\prime} 22,5^{\prime \prime}$ & $107^{\circ} 08^{\prime} 12,5$ \\
\hline 28 & 18 & Kali Mati & Balong & Teluk Jaya & Pakis Jaya & $06^{\circ} 03^{\prime} 10,2^{\prime \prime}$ & $107^{\circ} 07^{\prime} 57,2^{\prime \prime}$ \\
\hline 29 & 19 & $\begin{array}{c}\text { Muara Kanal/ } \\
\text { Sungai Bes }\end{array}$ & Balong & Teluk Jaya & Pakis Jaya & $06^{\circ} 02^{\prime} 45,6^{\prime \prime}$ & $107^{\circ} 08^{\prime} 12,5^{\prime \prime}$ \\
\hline 30 & 20 & Sungai Citarum & Puteran & Teluk Jaya & Pakis Jaya & $06^{\circ} 02 ’ 49,5^{\prime \prime}$ & $107^{\circ} 07^{\prime} 22,6^{\prime \prime}$ \\
\hline 31 & 28 & $\begin{array}{c}\text { Muara } \\
\text { Kamal/Sungai } \\
\text { Citarum } \\
\end{array}$ & Tanjung Jaya & $\begin{array}{l}\text { Teluk } \\
\text { Buyung }\end{array}$ & Pakis Jaya & $06^{\circ} 03 ' 29,7^{\prime \prime}$ & $107^{\circ} 08^{\prime} 29,2^{\prime \prime}$ \\
\hline 32 & 29 & Pulo Kamal & Pulo Kamal & Tanah Baru & Pakis Jaya & $06^{\circ} 01^{\prime} 16,8^{\prime \prime}$ & $107^{\circ} 08^{\prime} 14,5^{\prime \prime}$ \\
\hline 33 & 30 & $\begin{array}{l}\text { Situs Sumur } \\
\text { Candi }\end{array}$ & Gunteng Jaya & $\begin{array}{c}\text { Teluk } \\
\text { Buyung }\end{array}$ & Pakis Jaya & $06^{\circ} 03^{\prime} 17,1^{\prime \prime}$ & $107^{\circ} 09^{\prime} 01,1^{\prime \prime}$ \\
\hline 34 & 31 & Hulu Kali Asin & Kebun Kopi & $\begin{array}{c}\text { Teluk } \\
\text { Buyung }\end{array}$ & Pakis Jaya & $06^{\circ} 02^{\prime} 53,7^{\prime \prime}$ & $107^{\circ} 09^{\prime} 17,3$ \\
\hline 35 & 34 & $\begin{array}{l}\text { Situs Unur } \\
\text { Gundul }\end{array}$ & $\begin{array}{l}\text { Kobak } \\
\text { Kelapa }\end{array}$ & $\begin{array}{c}\text { Teluk } \\
\text { Buyung }\end{array}$ & Pakis Jaya & $06^{\circ} 02^{\prime} 55,2^{\prime \prime}$ & $107^{\circ} 09^{\prime} 12,7^{\prime \prime}$ \\
\hline 36 & 35 & $\begin{array}{l}\text { Situs Unur } \\
\text { Silinder }\end{array}$ & $\begin{array}{l}\text { Kramat } \\
\text { Duwur }\end{array}$ & $\begin{array}{c}\text { Teluk } \\
\text { Buyung }\end{array}$ & Pakis Jaya & $06^{\circ} 02^{\prime} 56,3^{\prime \prime}$ & $107^{\circ} 09^{\prime} 02,00^{\prime \prime}$ \\
\hline 37 & 36 & Situs Unur Asem & $\begin{array}{c}\text { Teluk } \\
\text { Buyung }\end{array}$ & $\begin{array}{c}\text { Teluk } \\
\text { Buyung }\end{array}$ & Pakis Jaya & $06^{\circ} 02^{\prime} 58,6^{\prime \prime}$ & $107^{\circ} 08^{\prime} 47,7^{\prime \prime}$ \\
\hline 38 & 37 & Situs Unur Serut & Gunteng & $\begin{array}{c}\text { Teluk } \\
\text { Buyung }\end{array}$ & Pakis Jaya & $06^{\circ} 03^{\prime} 19,7^{\prime \prime}$ & $107^{\circ} 09^{\prime} 03,99^{\prime \prime}$ \\
\hline 39 & 41 & Pantai Pakis & Pakis Satu & $\begin{array}{l}\text { Tanjung } \\
\text { Pakis }\end{array}$ & Pakis Jaya & $05^{\circ} 58^{\prime} 17,0 ”$ & $107^{\circ} 07^{\prime} 39,0 ”$ \\
\hline 40 & 42 & $\begin{array}{c}\text { Muara Sungai } \\
\text { Bungin } \\
\end{array}$ & $\begin{array}{l}\text { Muara } \\
\text { Bungin }\end{array}$ & $\begin{array}{l}\text { Tanjung } \\
\text { Pakis }\end{array}$ & Pakis Jaya & $05^{\circ} 56^{\prime} 21,7^{\prime \prime}$ & $107^{\circ} 05^{\prime} 55,7^{\prime \prime}$ \\
\hline 41 & 48 & $\begin{array}{c}\text { Sektor Cikande - } \\
\text { Kotak TP3 }\end{array}$ & -- & Telaga Jaya & Pakis Jaya & $06^{\circ} 01^{\prime} 51,00^{\prime \prime}$ & $107^{\circ} 09^{\prime} 33,00 ”$ \\
\hline 42 & 49 & $\begin{array}{c}\text { Sektor Cikande - } \\
\text { Kotak TP2 }\end{array}$ & --- & Telaga Jaya & Pakis Jaya & $06^{\circ} 01^{\prime} 50,00^{\prime \prime}$ & $107^{\circ} 09^{\prime} 32,00^{\prime \prime}$ \\
\hline 43 & 9 & Sungai Pondok & $\begin{array}{l}\text { Pondok } \\
\text { Kelapa }\end{array}$ & Tambak Sari & Tirta Jaya & $05^{\circ} 59^{\prime} 43,0^{\prime \prime}$ & $107^{\circ} 12^{\prime} 13,4^{\prime \prime}$ \\
\hline 44 & 10 & Sungai Cikiong & Tambak Sari & $\begin{array}{l}\text { Tambak } \\
\text { Sumur }\end{array}$ & Tirta Jaya & $05^{\circ} 59^{\prime} 47,6^{\prime \prime}$ & $107^{\circ} 11^{\prime} 22,6^{\prime \prime}$ \\
\hline 45 & 23 & Cisoma & Cisoma & $\begin{array}{l}\text { Tambak } \\
\text { Sumur }\end{array}$ & Tirta Jaya & $06^{\circ} 00^{\prime} 28,1^{\prime \prime}$ & $107^{\circ} 14^{\prime} 08,3^{\prime \prime}$ \\
\hline 46 & 24 & $\begin{array}{l}\text { Pertemuan Kali } \\
\text { Penjaringan } \\
\text { dengan Kali } \\
\text { Tambak Sumur }\end{array}$ & $\begin{array}{l}\text { Tambak } \\
\text { Sumur Dua }\end{array}$ & Tambak Sari & Tirta Jaya & $05^{\circ} 59^{\prime} 55,5^{\prime \prime}$ & $107^{\circ} 13^{\prime} 10,9^{\prime \prime}$ \\
\hline 47 & 25 & $\begin{array}{l}\text { Muara Sungai } \\
\text { Tambak Sumur }\end{array}$ & Muara & Tambak Sari & Tirta Jaya & $05^{\circ} 58^{\prime} 49,5^{\prime \prime}$ & $107^{\circ} 11^{\prime} 59,3^{\prime \prime}$ \\
\hline 48 & 51 & Temuan Perahu & Cinara & Tambak Sari & Tirta Jaya & $06^{\circ} 01^{\prime} 11,7^{\prime \prime}$ & $107^{\circ} 14^{\prime} 34,4^{\prime \prime}$ \\
\hline 49 & 52 & $\begin{array}{l}\text { Cabang Sungai } \\
\text { Citarum dengan } \\
\text { Sungai Bungin } \\
\text { (A4/2008) }\end{array}$ & --- & Pantai Bakti & $\begin{array}{c}\text { Muara } \\
\text { Gembong, } \\
\text { Kab. Bekasi }\end{array}$ & $05^{\circ} 59^{\prime} 25,6^{\prime \prime}$ & $107^{\circ} 05^{\prime} 04,1^{\prime \prime}$ \\
\hline 50 & 53 & $\begin{array}{l}\text { Cabang Sungai } \\
\text { Citarum dengan } \\
\text { Sungai Gembong }\end{array}$ & --- & Pantai Bakti & $\begin{array}{c}\text { Muara } \\
\text { Gembong, } \\
\text { Kab. Bekasi }\end{array}$ & $05^{\circ} 59^{\prime} 05,3 \prime$ & $107^{\circ} 02^{\prime} 19,7^{\prime \prime}$ \\
\hline 51 & 54 & $\begin{array}{l}\text { Cabang Sungai } \\
\text { Citarum dengan } \\
\text { Sungai Wetan }\end{array}$ & $\begin{array}{l}\text { Gobah } \\
\text { Prapatan }\end{array}$ & $\begin{array}{c}\text { Pantai } \\
\text { Bahagia }\end{array}$ & $\begin{array}{c}\text { Muara } \\
\text { Gembong, } \\
\text { Kab. Bekasi }\end{array}$ & $05^{\circ} 56^{\prime} 49,9^{\prime \prime}$ & $107^{\circ} 01^{\prime} 45,3^{\prime \prime}$ \\
\hline 52 & 55 & Sungai Citarum & --- & $\begin{array}{l}\text { Desa Muara } \\
\text { Bendera }\end{array}$ & $\begin{array}{c}\text { Muara } \\
\text { Gembong, } \\
\text { Kab. Bekasi } \\
\end{array}$ & $05^{\circ} 56^{\prime} 21,2 ”$ & $107^{\circ} 00^{\prime} 45,1^{\prime \prime}$ \\
\hline
\end{tabular}

Sumber: Intan, 2006; Intan, dkk., 2009 
Tabel 2:

Jenis Sedimen dan Warna Sedimen untuk Analisis Mineralogi

\begin{tabular}{|c|c|c|c|}
\hline Stasiun & Lokasi & Jenis Sedimen & Warna Sedimen \\
\hline 1 & Kali Asin & Lempung & Coklat muda \\
\hline 2 & Kali Kubang & Lempung & Coklat muda \\
\hline 3 & Pertemuan Kali Kubang dengan Kali Asin & Lempung & Coklat muda \\
\hline 4 & Kamal & Lempung pasiran & Coklat muda \\
\hline 5 & Muara Sungai Pakis & Pasir & Coklat keabu-abuan \\
\hline 6 & Muara Sungai Cipatar & Pasir & Coklat muda keabu-abuan \\
\hline 7 & Muara Sungai Sukajaya & Pasir & Coklat keabu-abuan \\
\hline 8 & Sungai terong Timur & Lempung pasiran & Coklat muda \\
\hline 9 & Sungai Pondok & Pasir & Coklat keabu-abuan \\
\hline 10 & Sungai Cikiong & Pasir & Coklat keabu-abuan \\
\hline 11 & Muara Sungai Cikiong & Pasir & Coklat keabu-abuan \\
\hline 12 & Sungai Citarum & Lempung & Coklat \\
\hline 13 & Sungai Citarum & Lempung & Coklat \\
\hline 14 & Sungai Citarum & Lempung & Coklat \\
\hline 15 & Sungai Citarum & Lempung & Coklat \\
\hline 16 & Sungai Citarum & Lempung & Coklat \\
\hline 17 & Kali Mati & Lempung & Coklat \\
\hline 18 & Kali Mati & Lempung & Coklat \\
\hline 19 & Muara Kanal/Sungai Bes & Lempung & Coklat \\
\hline 20 & Sungai Citarum & Lempung & Coklat \\
\hline 21 & Sungai Terong & Pasir & Coklat keabu-abuan \\
\hline 22 & Sungai Terong & Lempung pasiran & Coklat muda \\
\hline 23 & Cisoma & Pasir & Coklat keabu-abuan \\
\hline 24 & $\begin{array}{l}\text { Pertemuan Kali Penjaringan dengan Kali } \\
\text { Tambak Sumur }\end{array}$ & Pasir & Coklat keabu-abuan \\
\hline 25 & Muara Sungai Tambak Sumur & Pasir & Coklat keabu-abuan \\
\hline 26 & Sungai Citarum & Lempung & Coklat \\
\hline 27 & Sungai Citarum & Lempung & Coklat \\
\hline 28 & Muara Kamal/Sungai Citarum & Lempung & Coklat \\
\hline 29 & Pulo Kamal & Lempung & Coklat muda \\
\hline 30 & Situs Sumur Candi & Lempung & Coklat Kehitaman \\
\hline 31 & Hulu Kali Asin & Lempung & Coklat kehitaman \\
\hline 32 & Kali Bambu Kuning & Lempung pasiran & Coklat muda \\
\hline 33 & Kali Bambu Kuning & Pasir & Coklat keabu-abuan \\
\hline 34 & Situs Unur Gundul & Lempung & Coklat kehitaman \\
\hline 35 & Situs Unur Silinder & Lempung & Coklat kehitaman \\
\hline 36 & Situs Unur Asem & Lempung & Coklat kehitaman \\
\hline 37 & Situs Unur Serut & Lempung & Coklat kehitaman \\
\hline 38 & Situs Unur Lempeng & Lempung & Coklat kehitaman \\
\hline 39 & Situs Candi Blandongan & Lempung & Coklat kehitaman \\
\hline 40 & Basecamp Kaisin & Lempung & Coklat kehitaman \\
\hline 41 & Pantai Pakis & Pasir & Coklat tua \\
\hline 42 & Muara Sungai Bungin & Pasir & Coklat keabu-abuan \\
\hline $47 \mathrm{~A}$ & Sungai Citarum & Lempung & Coklat \\
\hline 48 & $\begin{array}{ll}\text { Sektor Cikande - Kotak TP3 } \\
\quad \text { Lapisan } 1 \\
\quad \text { Lapisan } 2 \\
\quad \text { Lapisan 3 } \\
\quad \text { Lapisan } 4 \\
\end{array}$ & $\begin{array}{l}\text { Lempung } \\
\text { Lempung } \\
\text { Lempung } \\
\text { Lempung }\end{array}$ & $\begin{array}{l}\text { Coklat muda } \\
\text { Coklat muda keabu-abuan } \\
\text { Coklat tua } \\
\text { Coklat muda keabu-abuan }\end{array}$ \\
\hline 49 & $\begin{array}{ll}\text { Sektor Cikande - Kotak TP2 } \\
\quad \text { Lapisan } 1 \\
\quad \text { Lapisan } 2 \\
\quad \text { Lapisan } 3 \\
\quad \text { Lapisan } 4 \\
\end{array}$ & $\begin{array}{l}\text { Lempung } \\
\text { Lempung } \\
\text { Lempung } \\
\text { Lempung }\end{array}$ & $\begin{array}{l}\text { Coklat muda } \\
\text { Coklat muda keabu-abuan } \\
\text { Coklat tua } \\
\text { Coklat muda keabu-abuan }\end{array}$ \\
\hline 50 & Tambak (temuan tembikar) & Lempung pasiran & Coklat keabu-abuan \\
\hline 51 & Temuan Perahu & Lempung pasiran & Coklat muda \\
\hline 52 & $\begin{array}{l}\text { Cabang Sungai Citarum dengan Sungai } \\
\text { Bungin (A4/2008) }\end{array}$ & Lempung pasiran & Coklat muda \\
\hline 53 & $\begin{array}{l}\text { Cabang Sungai Citarum dengan Sungai } \\
\text { Gembong }\end{array}$ & Lempung pasiran & Coklat muda \\
\hline 54 & $\begin{array}{l}\text { Cabang Sungai Citarum dengan Sungai } \\
\text { Wetan }\end{array}$ & Lempung pasiran & Coklat muda \\
\hline 55 & Sungai Citarum & Lempung Pasiran & Coklat muda \\
\hline 61 & $\begin{array}{ll}\text { Situs Batujaya/Sektor SPK - Kotak TP1 } \\
\qquad \quad \text { Lapisan } 1 \\
\bullet \quad \text { Lapisan } 2 \\
\bullet \quad \text { Lapisan } 3 \\
\end{array}$ & $\begin{array}{l}\text { Lempung pasiran } \\
\text { Pasir } \\
\text { Pasir }\end{array}$ & $\begin{array}{l}\text { Hitam kecoklatan } \\
\text { Hitam kecoklatan } \\
\text { Coklat keabu-abuan }\end{array}$ \\
\hline
\end{tabular}

Sumber: Intan, 2006; Intan, dkk., 2009

Jurnal Arkeologi Papua Vol. 12 Edisi No. 1 / Juni 2020 : 21-42 
Tabel 3: Hasil Analisis Mineralogi Per-Stasiun Pengamatan Di Wilayah Situs Batujaya dan sekitarnya

\begin{tabular}{|c|c|c|c|c|c|c|c|c|c|c|c|c|c|}
\hline \multirow{3}{*}{$\begin{array}{l}\text { Sta- } \\
\text { siun }\end{array}$} & \multirow{3}{*}{$\begin{array}{c}\text { Jenis } \\
\text { Sedimen }\end{array}$} & \multicolumn{12}{|c|}{ KOMPOSISI } \\
\hline & & \multicolumn{9}{|c|}{ Mineral } & \multicolumn{3}{|c|}{ Non Mineral } \\
\hline & & $\mathbf{K}$ & $\mathbf{P I}$ & $\mathbf{H}$ & $\mathbf{P i}$ & $\mathbf{B}$ & Or & Ov & Ob & $\mathbf{L}$ & Ffm & Fm & At \\
\hline 1 & Lempung & $\sqrt{ }$ & $\sqrt{ }$ & $\sqrt{ }$ & $\sqrt{ }$ & $\sqrt{ }$ & $\mathbf{x}$ & $\bar{x}$ & $\sqrt{ }$ & $\sqrt{ }$ & $\bar{x}$ & $\bar{x}$ & $\sqrt{ }$ \\
\hline 2 & Lempung & $\sqrt{ }$ & $\sqrt{ }$ & $\sqrt{ }$ & $\sqrt{ }$ & $\sqrt{ }$ & $\mathbf{x}$ & $\mathbf{x}$ & $\sqrt{ }$ & $\sqrt{ }$ & $\mathbf{x}$ & $\mathbf{x}$ & $\sqrt{ }$ \\
\hline 3 & Lempung & $\sqrt{ }$ & $\sqrt{ }$ & $\sqrt{ }$ & $\sqrt{ }$ & $\sqrt{ }$ & $\bar{x}$ & $\bar{x}$ & $\sqrt{ }$ & $\sqrt{ }$ & $\mathbf{x}$ & $\mathbf{x}$ & $\sqrt{ }$ \\
\hline 4 & Lempung & $\sqrt{ }$ & $\sqrt{ }$ & $\sqrt{ }$ & $\sqrt{ }$ & $\sqrt{ }$ & $\sqrt{ }$ & $\sqrt{ }$ & $\sqrt{ }$ & $\sqrt{ }$ & $\sqrt{ }$ & $\sqrt{ }$ & $\mathbf{x}$ \\
\hline 5 & Pasir & $\sqrt{ }$ & $\sqrt{ }$ & $\sqrt{ }$ & $\sqrt{ }$ & $\sqrt{ }$ & $\sqrt{ }$ & $\sqrt{ }$ & $\mathbf{x}$ & $\sqrt{ }$ & $\sqrt{ }$ & $\sqrt{ }$ & $\mathbf{x}$ \\
\hline 6 & Pasir & $\sqrt{ }$ & $\sqrt{ }$ & $\sqrt{ }$ & $\sqrt{ }$ & $\sqrt{ }$ & $\sqrt{ }$ & $\sqrt{ }$ & $\mathbf{x}$ & $\sqrt{ }$ & $\sqrt{ }$ & $\sqrt{ }$ & $\mathbf{x}$ \\
\hline 7 & Pasir & $\sqrt{ }$ & $\sqrt{ }$ & $\sqrt{ }$ & $\sqrt{ }$ & $\sqrt{ }$ & $\sqrt{ }$ & $\sqrt{ }$ & $\mathbf{x}$ & $\sqrt{ }$ & $\sqrt{ }$ & $\sqrt{ }$ & $\mathbf{x}$ \\
\hline 8 & Lempung pasiran & $\sqrt{ }$ & $\sqrt{ }$ & $\sqrt{ }$ & $\sqrt{ }$ & $\sqrt{ }$ & $\sqrt{\sqrt{ }}$ & $\sqrt{ }$ & $\mathbf{x}$ & $\sqrt{ }$ & $\sqrt{ }$ & $\sqrt{ }$ & $\mathbf{x}$ \\
\hline 9 & Pasir & $\sqrt{ }$ & $\sqrt{ }$ & $\sqrt{ }$ & $\sqrt{ }$ & $\sqrt{ }$ & $\sqrt{ }$ & $\sqrt{ }$ & $\mathbf{x}$ & $\sqrt{ }$ & $\sqrt{ }$ & $\sqrt{ }$ & $\mathbf{x}$ \\
\hline 10 & Pasir & $\sqrt{ }$ & $\sqrt{ }$ & $\sqrt{ }$ & $\sqrt{ }$ & $\sqrt{ }$ & $\sqrt{ }$ & $\sqrt{ }$ & $\mathbf{x}$ & $\sqrt{ }$ & $\sqrt{ }$ & $\sqrt{ }$ & $\mathbf{x}$ \\
\hline 11 & Pasir & $\sqrt{ }$ & $\sqrt{ }$ & $\sqrt{ }$ & $\sqrt{ }$ & $\sqrt{ }$ & $\sqrt{ }$ & $\sqrt{ }$ & $\mathbf{x}$ & $\sqrt{ }$ & $\sqrt{ }$ & $\sqrt{ }$ & $\mathbf{x}$ \\
\hline 12 & Lempung & $\sqrt{ }$ & $\sqrt{ }$ & $\sqrt{ }$ & $\sqrt{ }$ & $\sqrt{ }$ & $\mathbf{x}$ & $\bar{x}$ & $\sqrt{ }$ & $\sqrt{ }$ & $\mathbf{x}$ & $\mathbf{x}$ & $\mathbf{x}$ \\
\hline 13 & Lempung & $\sqrt{ }$ & $\sqrt{ }$ & $\sqrt{ }$ & $\sqrt{ }$ & $\sqrt{ }$ & $\mathbf{x}$ & $\overline{\mathbf{x}}$ & $\sqrt{ }$ & $\sqrt{ }$ & $\bar{x}$ & $\bar{x}$ & $\mathbf{x}$ \\
\hline 14 & Lempung & $\sqrt{ }$ & $\sqrt{ }$ & $\sqrt{ }$ & $\sqrt{ }$ & $\sqrt{ }$ & $\mathbf{x}$ & $\mathbf{x}$ & $\sqrt{ }$ & $\sqrt{ }$ & $\mathbf{x}$ & $\mathbf{x}$ & $\mathbf{x}$ \\
\hline 15 & Lempung & $\sqrt{ }$ & $\sqrt{ }$ & $\sqrt{1}$ & $\sqrt{ }$ & $\sqrt{ }$ & $\mathbf{x}$ & $\bar{x}$ & $\sqrt{ }$ & $\sqrt{ }$ & $\mathbf{x}$ & $\mathbf{x}$ & $\mathbf{x}$ \\
\hline 16 & Lempung & $\sqrt{ }$ & $\sqrt{ }$ & $\sqrt{ }$ & $\sqrt{ }$ & $\sqrt{ }$ & $\mathbf{x}$ & $\mathbf{x}$ & $\sqrt{ }$ & $\sqrt{ }$ & $\mathbf{x}$ & $\mathbf{x}$ & $\mathbf{x}$ \\
\hline 17 & Lempung & $\sqrt{ }$ & $\sqrt{ }$ & $\sqrt{ }$ & $\sqrt{ }$ & $\sqrt{ }$ & $\mathbf{x}$ & $\mathbf{x}$ & $\sqrt{ }$ & $\sqrt{ }$ & $\mathbf{x}$ & $\mathbf{x}$ & $\mathbf{x}$ \\
\hline 18 & Lempung & $\sqrt{ }$ & $\sqrt{ }$ & $\sqrt{ }$ & $\sqrt{ }$ & $\sqrt{ }$ & $\bar{x}$ & $\bar{x}$ & $\sqrt{ }$ & $\sqrt{ }$ & $\mathbf{x}$ & $\mathbf{x}$ & $\mathbf{x}$ \\
\hline 19 & Lempung & $\sqrt{ }$ & $\sqrt{ }$ & $\sqrt{ }$ & $\sqrt{ }$ & $\sqrt{ }$ & $\mathbf{x}$ & $\mathbf{x}$ & $\sqrt{ }$ & $\sqrt{ }$ & $\mathbf{x}$ & $\mathbf{x}$ & $\mathbf{x}$ \\
\hline 20 & Lempung & $\sqrt{ }$ & $\sqrt{ }$ & $\sqrt{ }$ & $\sqrt{ }$ & $\sqrt{ }$ & $\mathbf{x}$ & $\mathbf{x}$ & $\sqrt{ }$ & $\sqrt{ }$ & $\mathbf{x}$ & $\mathbf{x}$ & $\mathbf{x}$ \\
\hline 21 & Pasir & $\sqrt{ }$ & $\sqrt{ }$ & $\sqrt{ }$ & $\sqrt{ }$ & $\sqrt{ }$ & $\overline{\sqrt{ }}$ & $\sqrt{ }$ & $\mathbf{x}$ & $\sqrt{ }$ & $\sqrt{ }$ & $\sqrt{ }$ & $\mathbf{x}$ \\
\hline 22 & Lempung pasiran & $\sqrt{ }$ & $\sqrt{ }$ & $\sqrt{ }$ & $\sqrt{ }$ & $\sqrt{ }$ & $\sqrt{ }$ & $\sqrt{ }$ & $\mathbf{x}$ & $\sqrt{ }$ & $\sqrt{ }$ & $\sqrt{ }$ & $\mathbf{x}$ \\
\hline 23 & Pasir & $\sqrt{ }$ & $\sqrt{ }$ & $\sqrt{ }$ & $\sqrt{ }$ & $\sqrt{ }$ & $\sqrt{\sqrt{ }}$ & $\sqrt{ }$ & $\mathbf{x}$ & $\sqrt{ }$ & $\sqrt{ }$ & $\sqrt{ }$ & $\mathbf{x}$ \\
\hline 24 & Pasir & $\sqrt{ }$ & $\sqrt{ }$ & $\sqrt{ }$ & $\sqrt{ }$ & $\sqrt{ }$ & $\sqrt{ }$ & $\sqrt{ }$ & $\mathbf{x}$ & $\sqrt{ }$ & $\sqrt{ }$ & $\sqrt{ }$ & $\mathbf{x}$ \\
\hline 25 & Pasir & $\sqrt{ }$ & $\sqrt{ }$ & $\sqrt{ }$ & $\sqrt{ }$ & $\sqrt{ }$ & $\sqrt{ }$ & $\sqrt{ }$ & $\mathbf{x}$ & $\sqrt{ }$ & $\sqrt{ }$ & $\sqrt{ }$ & $\mathbf{x}$ \\
\hline 26 & Lempung & $\sqrt{ }$ & $\sqrt{ }$ & $\sqrt{ }$ & $\sqrt{ }$ & $\sqrt{ }$ & $\bar{x}$ & $\bar{x}$ & $\sqrt{ }$ & $\sqrt{ }$ & $\mathbf{x}$ & $\mathbf{x}$ & $\mathbf{x}$ \\
\hline 27 & Lempung & $\sqrt{ }$ & $\sqrt{ }$ & $\sqrt{ }$ & $\sqrt{ }$ & $\sqrt{ }$ & $\bar{x}$ & $\bar{x}$ & $\sqrt{ }$ & $\sqrt{ }$ & $\mathbf{x}$ & $\mathbf{x}$ & $\mathbf{x}$ \\
\hline 28 & Lempung & $\sqrt{ }$ & $\sqrt{ }$ & $\sqrt{ }$ & $\sqrt{ }$ & $\sqrt{ }$ & $\mathbf{x}$ & $\mathbf{x}$ & $\sqrt{ }$ & $\sqrt{ }$ & $\mathbf{x}$ & $\mathbf{x}$ & $\mathbf{x}$ \\
\hline 29 & Lempung & $\sqrt{ }$ & $\sqrt{ }$ & $\sqrt{ }$ & $\sqrt{ }$ & $\sqrt{ }$ & $\bar{x}$ & $\bar{x}$ & $\sqrt{ }$ & $\sqrt{ }$ & $\mathbf{x}$ & $\mathbf{x}$ & $\sqrt{ }$ \\
\hline 30 & Lempung & $\sqrt{ }$ & $\sqrt{ }$ & $\sqrt{ }$ & $\sqrt{ }$ & $\sqrt{ }$ & $\mathbf{x}$ & $\mathbf{x}$ & $\sqrt{ }$ & $\sqrt{ }$ & $\mathbf{x}$ & $\mathbf{x}$ & $\mathbf{x}$ \\
\hline 31 & Lempung & $\sqrt{ }$ & $\sqrt{ }$ & $\sqrt{ }$ & $\sqrt{ }$ & $\sqrt{ }$ & $\mathbf{x}$ & $\bar{x}$ & $\sqrt{ }$ & $\sqrt{ }$ & $\bar{x}$ & $\bar{x}$ & $\mathbf{x}$ \\
\hline 32 & Lempung pasiran & $\sqrt{ }$ & $\sqrt{ }$ & $\sqrt{ }$ & $\sqrt{ }$ & $\sqrt{ }$ & $\sqrt{ }$ & $\sqrt{ }$ & $\mathbf{x}$ & $\sqrt{ }$ & $\sqrt{ }$ & $\sqrt{ }$ & $\mathbf{x}$ \\
\hline 33 & Pasir & $\sqrt{ }$ & $\sqrt{ }$ & $\sqrt{ }$ & $\sqrt{ }$ & $\sqrt{ }$ & $\sqrt{ }$ & $\sqrt{ }$ & $\mathbf{x}$ & $\sqrt{ }$ & $\sqrt{ }$ & $\sqrt{ }$ & $\mathbf{x}$ \\
\hline 34 & Lempung & $\sqrt{ }$ & $\sqrt{ }$ & $\sqrt{ }$ & $\sqrt{ }$ & $\sqrt{ }$ & $\bar{x}$ & $\bar{x}$ & $\sqrt{ }$ & $\sqrt{ }$ & $\mathbf{x}$ & $\mathbf{x}$ & $\mathbf{x}$ \\
\hline 35 & Lempung & $\sqrt{ }$ & $\sqrt{ }$ & $\sqrt{ }$ & $\sqrt{ }$ & $\sqrt{ }$ & $\mathbf{x}$ & $\mathbf{x}$ & $\sqrt{ }$ & $\sqrt{ }$ & $\mathbf{x}$ & $\mathbf{x}$ & $\mathbf{x}$ \\
\hline 36 & Lempung & $\sqrt{ }$ & $\sqrt{ }$ & $\sqrt{ }$ & $\sqrt{ }$ & $\sqrt{ }$ & $\bar{x}$ & $\bar{x}$ & $\sqrt{ }$ & $\sqrt{ }$ & $\bar{x}$ & $\bar{x}$ & $\mathbf{x}$ \\
\hline 37 & Lempung & $\sqrt{ }$ & $\sqrt{ }$ & $\sqrt{ }$ & $\sqrt{ }$ & $\sqrt{ }$ & $\mathbf{x}$ & $\mathbf{x}$ & $\sqrt{ }$ & $\sqrt{ }$ & $\mathbf{x}$ & $\mathbf{x}$ & $\mathbf{x}$ \\
\hline 38 & Lempung & $\sqrt{ }$ & $\sqrt{ }$ & $\sqrt{ }$ & $\sqrt{ }$ & $\sqrt{ }$ & $\mathbf{x}$ & $\mathbf{x}$ & $\sqrt{ }$ & $\sqrt{ }$ & $\mathbf{x}$ & $\mathbf{x}$ & $\mathbf{x}$ \\
\hline 39 & Lempung & $\sqrt{ }$ & $\sqrt{ }$ & $\sqrt{ }$ & $\sqrt{ }$ & $\sqrt{ }$ & $\bar{x}$ & $\bar{x}$ & $\sqrt{ }$ & $\sqrt{ }$ & $\mathbf{x}$ & $\mathbf{x}$ & $\mathbf{x}$ \\
\hline 40 & Lempung & $\sqrt{ }$ & $\sqrt{ }$ & $\sqrt{ }$ & $\sqrt{ }$ & $\sqrt{ }$ & $\mathbf{x}$ & $\bar{x}$ & $\sqrt{ }$ & $\sqrt{ }$ & $\mathbf{x}$ & $\mathbf{x}$ & $\mathbf{x}$ \\
\hline 41 & Pasir & $\sqrt{ }$ & $\sqrt{ }$ & $\sqrt{ }$ & $\sqrt{ }$ & $\sqrt{ }$ & $\sqrt{\sqrt{ }}$ & $\sqrt{ }$ & $\mathbf{x}$ & $\sqrt{ }$ & $\sqrt{ }$ & $\sqrt{ }$ & $\mathbf{x}$ \\
\hline 42 & Pasir & $\sqrt{ }$ & $\sqrt{ }$ & $\sqrt{ }$ & $\sqrt{ }$ & $\sqrt{ }$ & $\sqrt{ }$ & $\sqrt{ }$ & $\mathbf{x}$ & $\sqrt{ }$ & $\sqrt{ }$ & $\sqrt{ }$ & $\mathbf{x}$ \\
\hline $47 \mathrm{~A}$ & Lempung & $\sqrt{ }$ & $\sqrt{ }$ & $\sqrt{ }$ & $\sqrt{ }$ & $\sqrt{ }$ & $\mathbf{x}$ & $\bar{x}$ & $\sqrt{ }$ & $\sqrt{ }$ & $\mathbf{x}$ & $\mathbf{x}$ & $\mathbf{x}$ \\
\hline \multirow[t]{4}{*}{48} & Lempung (Lap-1) & $\sqrt{ }$ & $\sqrt{ }$ & $\sqrt{ }$ & $\sqrt{ }$ & $\sqrt{ }$ & $\overline{\mathbf{x}}$ & $\mathbf{x}$ & $\sqrt{ }$ & $\sqrt{ }$ & $\mathbf{x}$ & $\mathbf{x}$ & $\sqrt{ }$ \\
\hline & Lempung (Lap-2) & $\sqrt{ }$ & $\sqrt{ }$ & $\sqrt{ }$ & $\sqrt{ }$ & $\sqrt{ }$ & $\mathbf{x}$ & $\mathbf{x}$ & $\sqrt{ }$ & $\sqrt{ }$ & $\mathbf{x}$ & $\mathbf{x}$ & $\mathbf{x}$ \\
\hline & Lempung (Lap-3) & $\sqrt{ }$ & $\sqrt{ }$ & $\sqrt{ }$ & $\sqrt{ }$ & $\sqrt{ }$ & $\bar{x}$ & $\sqrt{ }$ & $\sqrt{ }$ & $\sqrt{ }$ & $\mathbf{x}$ & $\mathbf{x}$ & $\mathbf{x}$ \\
\hline & Lempung (Lap-4) & $\sqrt{ }$ & $\sqrt{ }$ & $\sqrt{ }$ & $\sqrt{ }$ & $\sqrt{ }$ & $\mathbf{x}$ & $\sqrt{ }$ & $\sqrt{ }$ & $\sqrt{ }$ & $\bar{x}$ & $\bar{x}$ & $\mathbf{x}$ \\
\hline \multirow[t]{4}{*}{49} & Lempung (Lap-1) & $\sqrt{ }$ & $\sqrt{ }$ & $\sqrt{ }$ & $\sqrt{ }$ & $\sqrt{ }$ & $\mathbf{x}$ & $\mathbf{x}$ & $\sqrt{ }$ & $\sqrt{ }$ & $\mathbf{x}$ & $\mathbf{x}$ & $\sqrt{ }$ \\
\hline & Lempung (Lap-2) & $\sqrt{ }$ & $\sqrt{ }$ & $\sqrt{ }$ & $\sqrt{ }$ & $\sqrt{ }$ & $\bar{x}$ & $\bar{x}$ & $\sqrt{ }$ & $\sqrt{ }$ & $\mathbf{x}$ & $\mathbf{x}$ & $\mathbf{x}$ \\
\hline & Lempung (Lap-3) & $\sqrt{ }$ & $\sqrt{ }$ & $\sqrt{ }$ & $\sqrt{ }$ & $\sqrt{ }$ & $\mathbf{x}$ & $\sqrt{ }$ & $\sqrt{ }$ & $\sqrt{ }$ & $\mathbf{x}$ & $\mathbf{x}$ & $\mathbf{x}$ \\
\hline & Lempung (Lap-4) & $\sqrt{ }$ & $\sqrt{ }$ & $\sqrt{ }$ & $\sqrt{ }$ & $\sqrt{ }$ & $\mathbf{x}$ & $\sqrt{ }$ & $\sqrt{ }$ & $\sqrt{ }$ & $\mathbf{x}$ & $\mathbf{x}$ & $\mathbf{x}$ \\
\hline 50 & Lempung pasiran & $\sqrt{ }$ & $\sqrt{ }$ & $\sqrt{ }$ & $\sqrt{ }$ & $\sqrt{ }$ & $\sqrt{ }$ & $\sqrt{ }$ & $\mathbf{x}$ & $\sqrt{ }$ & $\sqrt{ }$ & $\sqrt{ }$ & $\mathbf{x}$ \\
\hline 51 & Lempung pasiran & $\sqrt{ }$ & $\sqrt{ }$ & $\sqrt{ }$ & $\sqrt{ }$ & $\sqrt{ }$ & $\sqrt{ }$ & $\sqrt{ }$ & $\mathbf{x}$ & $\sqrt{ }$ & $\sqrt{ }$ & $\sqrt{ }$ & $\mathbf{x}$ \\
\hline 52 & Lempung pasiran & $\sqrt{ }$ & $\sqrt{ }$ & $\sqrt{ }$ & $\sqrt{ }$ & $\sqrt{ }$ & $\mathbf{x}$ & $\mathbf{x}$ & $\sqrt{ }$ & $\sqrt{ }$ & $\mathbf{x}$ & $\mathbf{x}$ & $\sqrt{ }$ \\
\hline 53 & Lempung pasiran & $\sqrt{ }$ & $\sqrt{ }$ & $\sqrt{ }$ & $\sqrt{ }$ & $\sqrt{ }$ & $\mathbf{x}$ & $\mathbf{x}$ & $\sqrt{ }$ & $\sqrt{ }$ & $\mathbf{x}$ & $\mathbf{x}$ & $\sqrt{ }$ \\
\hline 54 & Lempung pasiran & $\sqrt{ }$ & $\sqrt{ }$ & $\sqrt{ }$ & $\sqrt{ }$ & $\sqrt{ }$ & $\mathbf{x}$ & $\mathbf{x}$ & $\sqrt{ }$ & $\sqrt{ }$ & $\mathbf{x}$ & $\mathbf{x}$ & $\sqrt{ }$ \\
\hline 55 & $\begin{array}{l}\text { Lempung pasiran } \\
\text { Coklat muda }\end{array}$ & $\sqrt{ }$ & $\sqrt{ }$ & $\sqrt{ }$ & $\sqrt{ }$ & $\sqrt{ }$ & $\sqrt{ }$ & $\sqrt{ }$ & $\bar{x}$ & $\sqrt{ }$ & $\sqrt{ }$ & $\sqrt{ }$ & $\bar{x}$ \\
\hline \multirow[t]{3}{*}{61} & $\begin{array}{l}\text { Lempung pasiran(Lap- } \\
\text { 1) }\end{array}$ & $\sqrt{ }$ & $\sqrt{ }$ & $\sqrt{ }$ & $\sqrt{ }$ & $\sqrt{ }$ & $\sqrt{ }$ & $\sqrt{ }$ & $\mathbf{x}$ & $\sqrt{ }$ & $\sqrt{ }$ & $\sqrt{ }$ & $\mathbf{x}$ \\
\hline & Pasir (Lap-2) & $\sqrt{ }$ & $\sqrt{ }$ & $\sqrt{ }$ & $\sqrt{ }$ & $\sqrt{ }$ & $\overline{\mathbf{x}}$ & $\sqrt{ }$ & $\mathbf{x}$ & $\sqrt{ }$ & $\sqrt{ }$ & $\overline{\mathbf{x}}$ & $\mathbf{x}$ \\
\hline & Pasir (Lap-3) & $\sqrt{ }$ & $\sqrt{ }$ & $\sqrt{ }$ & $\sqrt{ }$ & $\sqrt{ }$ & $\mathbf{x}$ & $\sqrt{ }$ & $\mathbf{x}$ & $\sqrt{ }$ & $\sqrt{ }$ & $\begin{array}{l}\mathbf{x} \\
\end{array}$ & $\mathbf{x}$ \\
\hline
\end{tabular}

Sumber: Intan, 2006; Intan, dkk., 2009 


\begin{tabular}{|c|c|c|c|c|c|}
\hline $\mathrm{K}$ & : $\quad$ Kuarsa & $\mathrm{Ov}$ & Olivin & & \\
\hline $\mathrm{Pl}$ & Plagioklas & $\mathrm{Ob}$ & Oksida besi & & \\
\hline $\mathrm{Pi}$ & Piroksen & $\mathrm{L}$ & Lempung & & \\
\hline $\mathrm{H}$ & Hornblende & Ffm & Fosil Mikroforaminifera & & \\
\hline B & Biotit & $\mathrm{Fm}$ & Fragmen moluska & $\sqrt{ }$ & Ada \\
\hline Or & : Orthoklas & At & Akar tumbuhan & $\mathbf{x}$ & : Tidak ada \\
\hline
\end{tabular}

\section{Geologi Laut}

Salah satu cabang dari ilmu geologi yang membahas tentang laut (marin) dan segala aspek pendukungnya adalah geologi laut. Dalam geologi laut, pembentukan pantai merupakan suatu masalah yang sangat penting untuk diuraikan, sebab perubahan suatu garis pantai purba dapat merekonstruksi bentuk dari suatu daratan. Pada masa lalu, pantai memiliki aspek ekonomi dengan digunakannya sebagai sarana transportasi (pelabuhan) dan juga pemukiman. Dengan demikian perkembangan garis pantai tentunya juga berpengaruh terhadap kondisi ekonomi daerah itu, dan juga berpengaruh terhadap perkembangan pemukiman di daerah tersebut. Studi perkembangan pantai berdasarkan aspek geologis di Situs Batujaya mempunyai arti penting dalam penentuan posisi situs, terutama menyangkut masalah erosi dan sedimentasi pantai.

\section{a. Pantai Wilayah Utara Karawang}

Wilayah Kabupaten Karawang sebagian besar tertutup dataran pantai yang luas yang terhampar di bagian pantai utara dan merupakan batuan sedimen yang dibentuk oleh bahanbahan lepas, terutama endapan laut dan aluvium vulkanik. Di bagian tengah ditempati oleh perbukitan, terutama dibentuk oleh batuan sedimen, sedangkan di bagian Selatan terletak Gunung Sanggabuana dengan ketinggian \pm 1.291 meter di atas permukaan laut. Sesuai dengan bentuk morfologinya, Kabupaten Karawang terdiri dari dataran rendah (Badan Pusat Statistik, 2019).

Data kelerengan pantai di daerah penelitian ternyata berhubungan erat dengan besarnya ukuran butir pasir. Pantai di wilayah utara Karawang atau Situs Batujaya dan sekitarnya dengan lereng yang sangat landai mempunyai materi pantai yang berukuran dari halus $(1 / 8-1 / 4 \mathrm{~mm})$ hingga sangat halus $(1 / 16$ - 1/8) (Gambar 7). (King (1959) 
berpendapat bahwa nilai sudut lereng pantai tergantung dari bermacam-macam faktor, antara lain permeabilitas, panjang gelombang laut, ukuran butir dan kecuraman gelombang laut. Studi terakhir King (1959) lebih memperkuat pendapat bahwasanya ukuran butir adalah faktor yang paling menentukan. Jika sudut lereng landai (rendah) maka pantai tersebut mempunyai ukuran pasir (materi) halus, demikian juga sebaliknya, lereng bersudut besar biasanya mengandung pasir berukuran kasar (King, 1959). Pada pantai di wilayah utara Karawang, hipotesis tersebut cocok, yaitu mempunyai materinya semata-mata berupa pasir halus. Apabila diperhatikan secara makro, kenampakan wilayah yang membentang dari daerah Bogor ke arah utara hingga pantai utara Jawa Barat pada umumnya akan memperlihatkan bahwa daerah-daearah tersebut memiliki ciri-ciri bentuk permukaan bumi yang bergelombang atau cembung, sebagai akibat adanya peralihan dari Blok Bogor yang dipengaruhi oleh pembentukan pegunungan Kuarter Muda di wilayah itu. Selanjutnya makin ke utara makin landai. Oleh karena bentuk permukaannya bergelombang maka pada daerah-daerah yang lebih rendah dapat terbentuk aliran sungai baik besar maupun kecil yang menyebar menyerupai kipas yang sebagian mengalir ke arah utara dan barat laut secara radial (Verstappen 1953:4345; Soeroso, 1995).

Berdasarkan hasil penelitian geomorfologi oleh Verstappen (1953:4345) diketahui bahwa pembentukan daerah yang berkipas dan membentang dari wilayah Bogor hingga ke daerah pantai utara itu baru terjadi sejak Masa Holosen Tua (8000-10000 tahun yang lalu) atau setidak-tidaknya Masa Holosen Muda (1000-2000 tahun yang lalu). Oleh karena kecepatan pengendapan di daerah penelitian cukup tinggi, maka menurut perkiraan Verstappen (1953:43-45) daerah dataran yang dikenal dengan Blok Jakarta itu, baru terbentuk sejak sekitar 5000 tahun yang lalu (Verstappen 1953:43-45; Soeroso, 1995).

Menurut Djubiantono, 1996 (dalam Yondri, 1996), data geologi menunjukkan bahwa Pulau Jawa terbentuk oleh adanya pengangkatan secara progresif dari barat ke timur. Di mana pada sekitar akhir Pliosen $( \pm 2$ juta tahun yang lalu) dan selama Plestosen Bawah (hingga 700.000 tahun yang lalu) lahirnya bagian timur Pulau Jawa benarbenar terasa. Berdasarkan hal tersebut, 
oleh Djubiantono, 1996 (dalam Yondri, 1996) disimpulkan bahwa kawasan bagian barat Pulau Jawa (Jawa Barat dan Banten), secara geologis merupakan kawasan yang paling tua dibandingkan dengan kawasan lain seperti Jawa Tengah ataupun Jawa Timur, karena secara geologis kawasan barat Pulau Jawa lebih awal terbentuk (Yondri, 1996).

\section{b. Garis pantai utara Karawang pada Abad ke-5 Masehi}

Penentuan garis pantai pada abad ke-5 Masehi didasarkan atas temuantemuan gerabah-gerabah Arikamedu (gerabah India) di Situs Batujaya, yang dimulai abad 1 Masehi hingga abad 5 masehi (Indradjaya, 2012). Olehnya itu, tim survei lingkungan sepakat untuk mengambil batas masa termuda yaitu Abad ke-5 Masehi atau 1500 tahun yang lalu. Penentuan garis pantai 1500 tahun yang lalu di wilayah utara Karawang atau di Situs Batujaya dan sekitarnya, didasarkan atas:

- Pengamatan bentang alam (khususnya bentang alam pantai)

- Hasil Analisis Mineralogi terhadap 52 sampel sedimen

- Menentukan batas-batas bagian terdalam dari pohon bakau yang sejajar garis pantai
Pada survei lingkungan, telah dapat ditentukan batas terdalam pohon bakau dari arah timur ke arah barat yang sejajar garis pantai sebagai berikut:

Stasiun-4: Dusun Kamal (Gambar 8)

Stasiun-8: Dusun Sungai Terong Timur (Gambar 9)

Stasiun-22: Sungai Terong di Dusun Sungai Terong (Gambar 10)

* Stasiun 23: Dusun Cisoma (Gambar 11)

Stasiun-32: Kali Bambu Kuning di Dusun Karang Anyar (Gambar 12)

- Stasiun-53: (15/2009) Cabang Sungai Citarum dengan Sungai Gembong: di Desa Pantai Mekar, Kec. Muara Gembong, Kab. Bekasi (Gambar 13)

Stasiun A1: Dusun Sungai Kobah, Desa Solokan, Kecamatan Pakis Jaya

* Stasiun A2: Desa Tanjung Mekar, Kecamatan Pakis Jaya

Stasiun A3: Desa Tanjung Pakis, Kecamatan Pakis Jaya

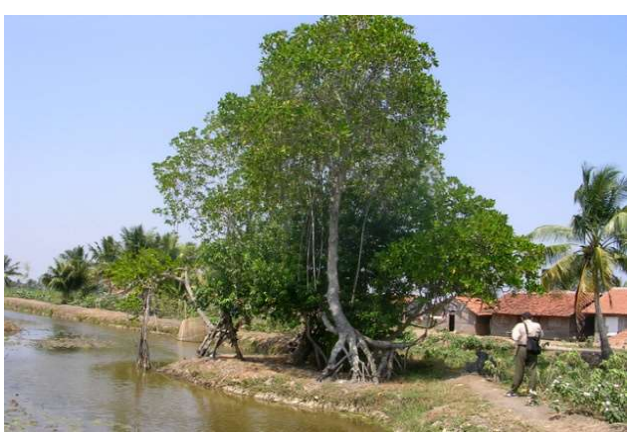

Gambar 8. Lingkungan di Stasiun-4 di Dusun Kamal, yang merupakan batas garis pantai pada abad ke-5 masehi (Sumber Dokumentasi Puslit Arkenas, 2009) 


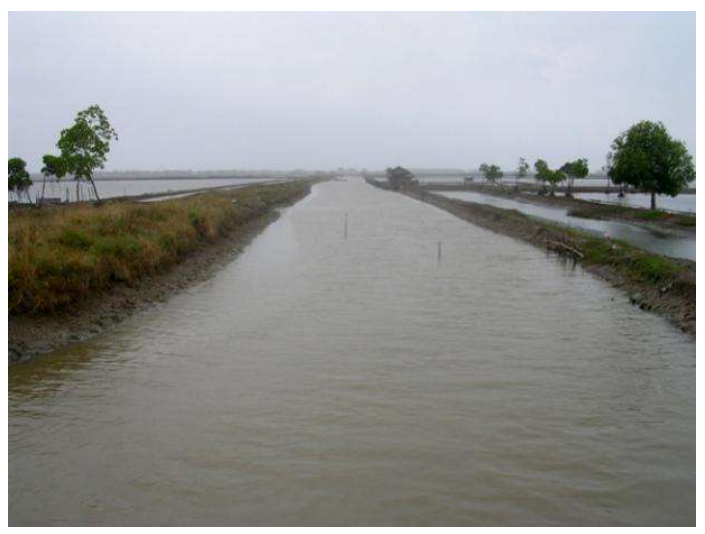

Gambar 9. Lingkungan di Stasiun-8 di Dusun Sungai Terong Timur, yang merupakan batas garis pantai pada abad ke-5 masehi (Sumber Dokumentasi Puslit Arkenas, 2009)

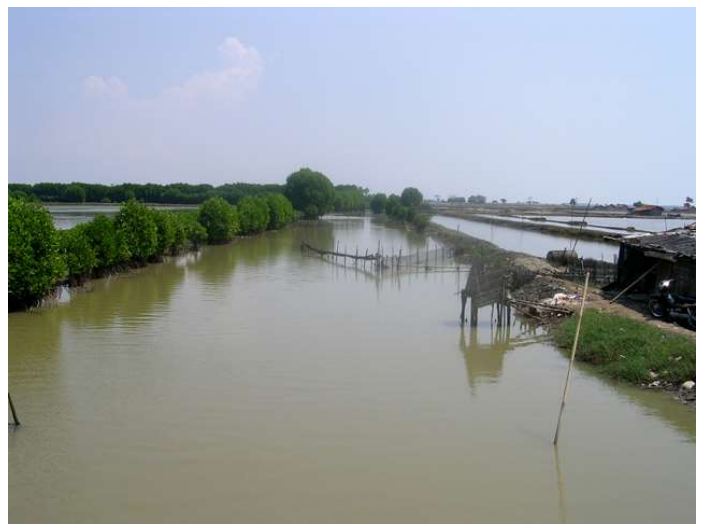

Gambar 10. Lingkungan di Stasiun-22 Sungai

Terong di Dusun Sungai Terong, yang merupakan batas garis pantai pada abad ke-5 masehi (Sumber Dokumentasi Puslit Arkenas, 2009)

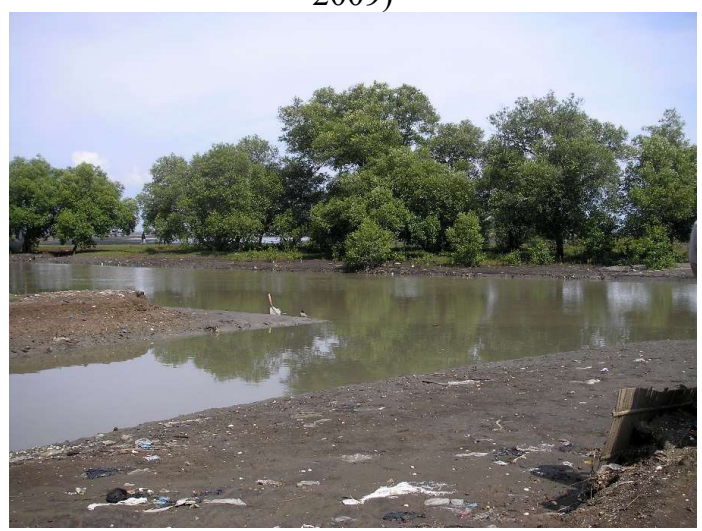

Gambar 11. Lingkungan di Stasiun-23 di Dusun Cisoma, yang merupakan batas garis pantai pada abad ke-5 masehi (Sumber Dokumentasi Puslit Arkenas, 2009)
Tabel 4:

Jarak dari Stasiun Pengaman ke Laut Jawa

\begin{tabular}{|c|l|c|c|}
\hline NO & STASIUN & LAUT & $\begin{array}{c}\text { JARAK } \\
\text { (Km) }\end{array}$ \\
\hline 01 & Stasiun-4 & Laut Jawa & 3,825 \\
\hline 02 & Stasiun-8 & Laut Jawa & 4,125 \\
\hline 03 & Stasiun-21 & Laut Jawa & 3,3 \\
\hline 04 & Stasiun-22 & Laut Jawa & 3,5 \\
\hline 05 & Stasiun-23 & Laut Jawa & 4,25 \\
\hline 06 & Stasiun-33 & Laut Jawa & 33,25 \\
\hline 07 & Stasiun-53 & Laut Jawa & 3,4 \\
\hline
\end{tabular}

Sumber: Intan, 2006; Intan, dkk., 2009

Dari jarak antara batas darat dan laut, yang didasarkan atas hasil analisis mineralogi dan ditunjang dengan perkembangan bakau pada lima titik pengamatan yaitu 3,6 kilometer yang dianggap seusia dengan situs-situs tersebut yaitu 1500 tahun yang lalu (berdasarkan gerabah arikamedu), maka penambahan daratan adalah $\pm 2,4$ meter/tahun (Gambar 12).

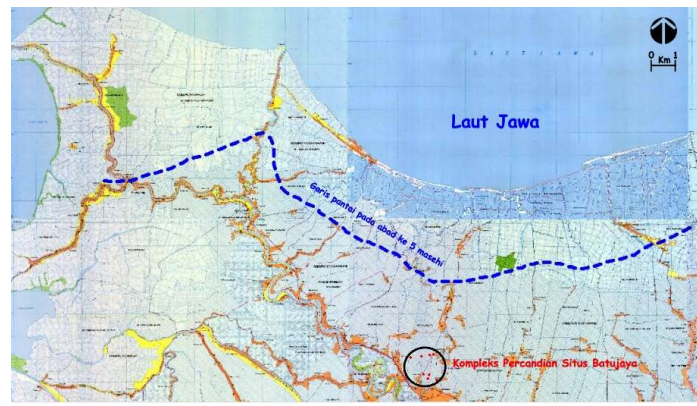

Gambar 12. Garis pantai pada abad ke 5 Masehi pada Peta Rupa Bumi Indonesia (Sumber:

Bakosurtanal, 1990, 1991, dan 2001, dengan pengolahan)

Penentuan garis pantai di utara Karawang atau Situs Batujaya dan sekitarnya pada abad ke-5 Masehi, yang didasarkan pada perkembangan pohon bakau, sesuai pula 


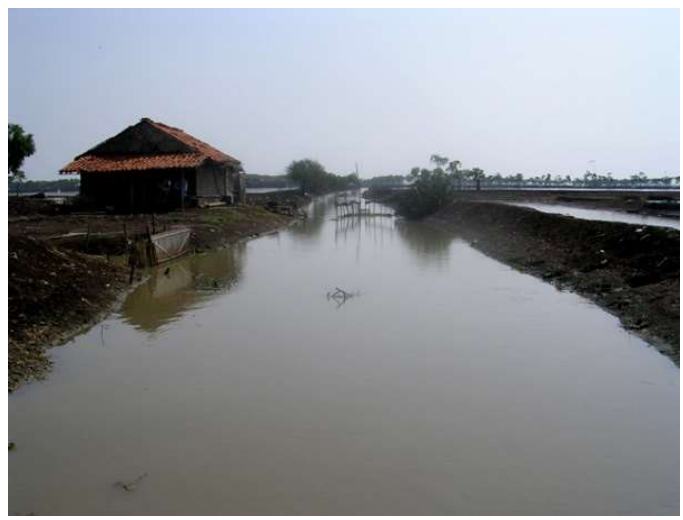

Gambar 13: Lingkungan di Stasiun-32 Kali Bambu Kuning di Dusun Karang Anyar, yang merupakan batas garis pantai pada abad ke-5 masehi (Sumber Dokumentasi Puslit Arkenas, 2009)

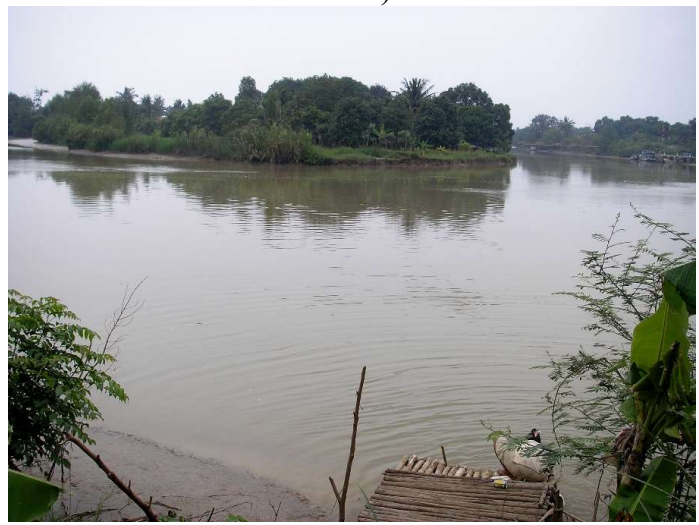

Gambar 14: Cabang Sungai Citarum dengan Sungai Gembong: (Stasiun-53) di Desa Pantai Mekar, Kec. Muara Gembong, Kab. Bekasi (Sumber Dokumentasi Puslit Arkenas, 2009)

dengan hasil penelitian dari Verstappen (1953:43-45; Soeroso, 1995) yang menyebutkan bahwa proses pembentukan garis pantai di wilayah pantai utara Jawa Barat yang terletak di sebelah barat dan timur Sungai Citarum sangat dipengaruhi oleh iklim dan materi yang terendapkan dari daerah pedalaman (Verstappen, 1953:43-45; Soeroso, 1995).
Lebih lanjut disebutkan oleh Verstappen (1953: 43-45) bahwa pada musim hujan arus laut secara terusmenerus akan mengalir ke arah timur dan dengan sendirinya lumpur yang terendapkan oleh Sungai Citarum juga akan membelok ke arah timur. Sementara itu, pada musim angin timur (musim kemarau) angin laut akan mengalir ke arah barat dan pada saat itu pula hanya sedikit lumpur yang diendapkan (Gambar $15)$.

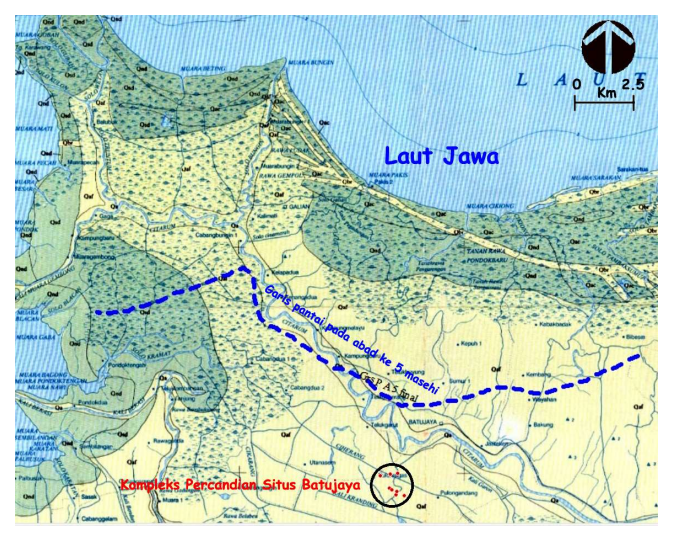

Gambar 15: Garis pantai pada abad ke 5 Masehi pada peta geologi (Sumber: Achdan dkk., 1992, dengan pengolahan)

Hasil penelitian yang dilakukan oleh Verstappen (1953:43-45) tentang perubahan garis pantai Teluk Jakarta, menunjukkan bahwa tidak kurang dari 25 tempat di sepanjang garis pantai utara Jawa Barat, yang memanjang dari daerah muara Cisadane hingga ujung Karawang, telah mengalami perubahan, baik karena karena oleh abrasi maupun karena akresi. Daerah-daerah yang paling cepat 
mengalami penambahan garis pantai terletak di sebelah timur Teluk Jakarta terutama di delta-delta Kali Bekasi dan Sungai Citarum serta sebagian di sekitar Sungai Angke (Verstappen 1953:43-45; Soeroso, 1995). Apa yang dikatakan oleh (Verstappen 1953:43-45) dan Soeroso (1995), sesuai dengan pantai di situs Batujaya, yaitu proses akresi lebih dominan dari pada proses abrasi, sehingga membentuk dataran-dataran baru di utara situs Batujaya.

Berdasarkan data dari Verstappen (1953:43-45) tersebut di atas tampak bahwa daerah-daerah muara sungai cenderung membentuk tanjung-tanjung yang menjorok ke arah laut. Namun demikian karena adanya pengaruh arus air laut yang mengalir dari arah utara, baratlaut dan timurlaut, maka arus air laut tersebut telah membatasi terbentuknya tanjung-tanjung di muara-muara sungai. Akibat lebih lanjut karena adanya pengaruh yang kuat antara arah angin terhadap arus laut, maka akresi di wilayah utara Karawang akan berlangsung sangat cepat sebagai akibat dari pengaruh angin barat yang melimpahkan materi cukup besar, sedangkan pada musim angin timur hanya sebagian kecil materi yang dapat diendapkan. Selain materi yang terangkut oleh aliran sungai, maka materi yang dilimpahkan kembali dari laut adalah pasir batu karang (coral reef) yang kemudian akan membentuk beting pantai. Luas beting pantai di wilayah Batujaya sekitar 7,5 $\mathrm{km}^{2}$ sedangkan di Cibuaya sekitar 2,5 km² (Verstappen 1953:43-45; Soeroso, 1995).

\section{PENUTUP}

Berdasarkan hasil pengamatan lapangan lingkungan, maka penelitian tentang perubahan garis pantai di wilayah Karawang, dipusatkan di Situs Batujaya dan sekitarnya, dapat disimpulkan bahwa bentang alamnya termasuk pada satuan morfologi dataran (0-2\%), dengan ketinggian situs secara umum adalah 1 hingga 3 meter dpl. Pembentuk satuan morfologi kawasan situs adalah endapan alluvial, dan kompleks Situs Batujaya terletak pada satuan morfologi dataran. Pantai di wilayah utara Situs Batujaya memiliki kelerengan yang sangat landai antara $2^{\circ}-4^{\circ}$, dan menunjukkan materi pantai yang berupa pasir halus.

Secara fisik, pembentukan pantai utara Karawang dan Situs Batujaya merupakan land deposition coast atau dune coast yang dipengaruhi oleh iklim, proses aluvial (alluviation), dan aksi 
gelombang (wave action). Sungai-sungai yang mengalir di wilayah Situs Batujaya dan sekitarnya menunjukkan dua jenis bentukan, yaitu sungai alam yang berstadium tua, Sungai Citarum, dan sungai yang dimodifikasi oleh manusia, antara lain Kali Asin, Kali Kubang, Sungai Terong, Sungai Tambak Sumur, dan Sungai Bantarkuning. Sungai-sungai tersebut berkontribusi dalam pembentukan kawasan Situs Batujaya. Bukti-bukti tersebut didukung oleh satuan batuan yang menyusun kawasan Situs Batujaya dan sekitarnya, yaitu endapan-endapan yang saling tumpangtindih perpaduan antara endapan kuarter, hasil limpahan banjir dan endapan sedimen laut yang mempunyai sebaran datar dan tegak.

Di lain pihak, penentuan garis pantai abad ke-5 Masehi juga diamati berdasarkan jarak batas antara darat dan laut, yang dilandasi perkembangan gugusan pohon bakau pada lima titik pengamatan yang dianggap seusia dengan Situs Batujaya berdasarkan gerabah Arikamedu.

\section{DAFTAR PUSTAKA}

Achdan A., Sudana D., 1992 Peta Geologi Lembar Karawang, Jawa. Pusat Penelitian dan Pengembangan Geologi, Bandung.

Bemmelen, R.W. van, 1949 The Geology of Indonesia. vol.IA, Martinus Nijhoff, The Hague.

BPS 2019 Kabupaten Karawang Dalam Angka 2019 Badan Pusat Statistik Kabupaten Karawang.

Cotton, C.A. 1951, Accidents and Interruptions in the Cycle of Marine Erosion. Geogr. Jour. 117: 343-349.

Cotton, C.A. 1954, Deductive Morphology and Genetics Classification of Coast. Sci. Monthly, 78: 163-181.

Desaunettes, J R. 1977. "Catalogue of Landforms for Indonesia": Examples of a Physiographic Approach to Land Evaluation for Agricultural Development." 
Unpublished. Bogor: Trust Fund of the Government of Indonesia Food and Agriculture Organization.

Djafar Hasan, 2010 Kompleks Percandian Batujaya Rekonstruksi Sejarah Kebudayaan

Daerah Pantai Utara Jawa Barat. Ěcole française d'Extreme -Orient (EFEO).

Indradjaya Agustijanto, 2005 Awal Persentuhan Agama Buddha di Daerah Pantai Utara

Jawa Barat (Kompleks Percandian Batujaya). Dalam Supratikno Rahardjo (ed.),

Religi dalam Dinamika Masyarakat, hal. 45-49, Bandung: Ikatan Ahli Arkeologi Indonesia.

Indradjaya Agustijanto, dkk. 2012 Awal Sejarah di Pantai Utara Jawa Barat Komplek

Percandian Batujaya Karawang, Jawa Barat. Laporan Penelitian Arkeologi.

Pusat Arkeologi Nasional, Kementerian Pendidikan dan Kebudayaan.

Intan S. Fadhlan. M. Vita, Istari Rita, 1992 Situs Batujaya, Kab. Karawang, Jawa Barat.

Laporan Penelitian Arkeologi - Bidang Arkeometri, Pusat Penelitian Arkeologi Nasional.

Intan S. Fadhlan. M. 2006. Geologi Situs Batujaya, Kabupaten Karawang, Jawa Barat.

Bagian Laporan Penelitian Arkeologi. Pusat Penelitian dan Pengembangan Arkeologi Nasional. Departemen Kebudayaan dan Pariwisata.

Intan S. Fadhlan M. Arfian 2009. Garis Pantai (Situs Batujaya) di Wilayah Karawang, Provinsi Jawa Barat Pada Abad 5 Masehi. Laporan Penelitian Arkeologi Kajian Arkeometri. Pusat Penelitian dan Pengembangan Arkeologi Nasional. Departemen Kebudayaan dan Pariwisata.

King, C.A.M. 1957. Beaches and Coast. 1st ed., Edwards \& Arnold, London, 570pp.

Kraus, Hunt, Ramsdell. 1959. Mineralogy, An Introduction to the Study of Minerals and Crystals. McGraw-Hill Book Company, Inc. New York, Toronto, London, Kogakusha Company, Ltd. Tokyo.

King, C.A.M. 1957. Beaches and Coast. 1st ed., Edwards \& Arnold, London, 570pp.

Kraus, Hunt, Ramsdell, 1959. Mineralogy, An Introduction to the Study of Minerals and Crystals. McGraw-Hill Book Company, Inc. New York, Toronto, London, Kogakusha Company, Ltd. Tokyo.

Lobeck, A.K. 1939. Geomorphology. McGraw-Hill Book Company, Inc., New York and Company. 
Ong, H.L. dkk, 1981. Mineralogi. Laboratorium Mineralogi, Departemen Teknik Geologi ITB, Bandung.

Prasetyo, Budi Teguh, 1987. Situs-Situs Arkeologi Batujaya dan Lingkungannya. Skripsi, Fakultas Sastra Universitas Indonesia.

Shepard, F.P. 1963. Submarine Geology. Harper \& Row, 2nd ed., 557pp.

Soeroso, 1995. Pola Persebaran Situs Bangunan Masa Hindu-Buda di Pesisir Utara Wilayah Batujaya dan Cibuaya, Jawa Barat: Tinjauan Ekologi. Tesis S-2, Program Pasca Sarjana, Universitas Indonesia, Jakarta.

Thornbury,W.D. 1964. Principle of Geomorphology. New York, London, John Wiley and sons, inc.

Todd D.K. 1980. Groundwater Hidrology. John Wiley \& Sons Inc, New York.

Verstappen Herman Theodoor 1953 Djakarta Bay, a geomorphological study on shoreline development. Thesis, Utrecht, pp. 101, 1953.

Yondri Lutfi. 1996. Penelusuran Jejak Jalur Migrasi Pertama di Bagian Barat Pulau Jawa (Salah Satu Prospek Penelitian Prasejarah di Jawa Barat). EHPA Ujung Pandang, 20-26 September 1996.

Zaim Yahdi. dkk. 1998. Perubahan Garis Pantai Utara Jakarta Kala Plistosen Atas-Resen: Data Baru Untuk Penelitian Arkeologi Jakarta. PIA-IAAI, Cipayung, Bogor, 919 Februari 1998. 